\title{
Effect of regional precursor emission controls on long-range ozone transport - Part 1: Short-term changes in ozone air quality
}

\author{
J. J. West ${ }^{1}$, V. Naik ${ }^{2, *}$, L. W. Horowitz ${ }^{3}$, and A. M. Fiore ${ }^{3}$ \\ ${ }^{1}$ University of North Carolina, Chapel Hill, NC, USA \\ ${ }^{2}$ Princeton University, Princeton, NJ, USA \\ ${ }^{3}$ NOAA Geophysical Fluid Dynamics Laboratory, Princeton, NJ, USA \\ *now at: ATMOS Research and Consulting, Lubbock, TX, USA
}

Received: 16 February 2009 - Published in Atmos. Chem. Phys. Discuss.: 16 March 2009

Revised: 11 July 2009 - Accepted: 17 July 2009 - Published: 21 August 2009

\begin{abstract}
Observations and models demonstrate that ozone and its precursors can be transported between continents and across oceans. We model the influences of $10 \%$ reductions in anthropogenic nitrogen oxide $\left(\mathrm{NO}_{\mathrm{x}}\right)$ emissions from each of nine world regions on surface ozone air quality in that region and all other regions. In doing so, we quantify the relative importance of long-range transport between all sourcereceptor pairs, for direct short-term ozone changes. We find that for population-weighted concentrations during the threemonth "ozone-season", the strongest inter-regional influences are from Europe to the Former Soviet Union, East Asia to Southeast Asia, and Europe to Africa. The largest influences per unit of $\mathrm{NO}_{\mathrm{x}}$ reduced, however, are seen for source regions in the tropics and Southern Hemisphere, which we attribute mainly to greater sensitivity to changes in $\mathrm{NO}_{\mathrm{x}}$ in the lower troposphere, and secondarily to increased vertical convection to the free troposphere in tropical regions, allowing pollutants to be transported further. Results show, for example, that $\mathrm{NO}_{\mathrm{x}}$ reductions in North America are $220 \%$ as effective per unit $\mathrm{NO}_{\mathrm{x}}$ in reducing ozone in Europe during summer, as $\mathrm{NO}_{\mathrm{x}}$ reductions from Europe itself. Reducing anthropogenic emissions of non-methane volatile organic compounds (NMVOCs) and carbon monoxide (CO) by $10 \%$ in selected regions, can have as large an impact on long-range ozone transport as $\mathrm{NO}_{\mathrm{x}}$ reductions, depending on the source region. We find that for many source-receptor pairs, the season of greatest long-range influence does not coincide with the season when ozone is highest in the receptor region. Reducing $\mathrm{NO}_{\mathrm{x}}$ emissions in most source regions causes a larger decrease in export of ozone from the source region than in ozone production outside of the source region.
\end{abstract}

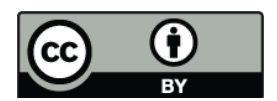

Correspondence to: J. J. West (jasonwest@unc.edu)

\section{Motivation}

Tropospheric ozone is a pervasive air pollutant that affects human health, crop productivity, and natural ecosystems. Ozone is also a major greenhouse gas, and changes in emissions of ozone precursors - nitrogen oxides $\left(\mathrm{NO}_{\mathrm{x}}\right)$, nonmethane volatile organic compounds (NMVOCs), carbon monoxide $(\mathrm{CO})$, and methane $\left(\mathrm{CH}_{4}\right)$ - affect the global climate through a linked chemical system (Forster et al., 2007).

Ozone has traditionally been addressed as a local air pollutant, through reductions in emissions of NMVOCs and $\mathrm{NO}_{\mathrm{x}}$. Over the past two decades, ozone has been increasingly recognized as a regional pollutant, and $\mathrm{NO}_{\mathrm{x}}$ emission reductions have received greater emphasis (National Research Council, 1991). More recently, it has been shown that anthropogenic emissions of ozone precursors affect ozone concentrations over larger spatial scales, including between continents, as demonstrated through direct surface observations, satellite measurements, and modeling studies (see Akimoto, 2003; Holloway et al., 2003; Stohl, 2004; Task Force on Hemispheric Transport of Air Pollution, 2007; and references therein). Observations and modeling studies have likewise shown that global background concentrations of ozone have increased since preindustrial times, including at the surface (Vingarzan, 2004). Growth in this global background has been attributed to anthropogenic emissions of ozone precursors, mainly $\mathrm{NO}_{\mathrm{x}}$ and $\mathrm{CH}_{4}$ (Wang and Jacob, 1998; Lelieveld and Dentener, 2000).

The inter-continental transport of ozone results from both the formation of ozone over source regions, with subsequent transport, and the transport of ozone precursors. Because the lifetime of ozone in the troposphere (days to months, with a tropospheric mean of $\sim 22$ days, Stevenson et al., 2006) is generally much longer than typical transport times between continents separated by oceans (5-10 days), the inter-continental transport of ozone may be substantial. The

Published by Copernicus Publications on behalf of the European Geosciences Union. 
lifetime of ozone is also generally much longer than that of $\mathrm{NO}_{\mathrm{x}}$ (roughly 1-2 days), which would suggest that the transport of ozone dominates over the transport of $\mathrm{NO}_{\mathrm{x}}$. However, ozone formation in remote regions of the troposphere is commonly limited by $\mathrm{NO}_{\mathrm{x}}$, and therefore the fraction of $\mathrm{NO}_{\mathrm{x}}$ emissions that is transported out of polluted continental regions can be relatively more effective at producing ozone. Further, a fraction of $\mathrm{NO}_{\mathrm{x}}$ from polluted source regions is converted to reservoir species, such as the peroxyacyl nitrates (PANs), which persist longer in the free troposphere before subsiding and decomposing to give $\mathrm{NO}_{\mathrm{x}}$, thereby producing ozone further from the sources (Moxim et al., 1996; Wang et al., 1998; Horowitz and Jacob, 1999).

Previous modeling studies of the inter-continental transport of ozone and its precursors have mainly considered transport between two geographical regions, such as the influence of Asian emissions on air quality in North America (Jacob et al., 1999; Berntsen et al., 1999; Yienger et al., 2000; Hudman et al., 2004; Zhang et al., 2008), North America and Europe (Li et al., 2002), and Europe and Asia (Wild et al., 2004). Other studies have addressed the pathways for the export of pollution from or import to populated regions of interest (Stohl, 2004), including the export from the USA (Liang et al., 1998), Europe (Duncan and Bey, 2004; Duncan et al., 2008), and Asia (Newell and Evans, 2000; Phadnis and Carmichael, 2000; Mauzerall et al., 2000; Heald et al., 2003; Liu et al., 2003; Kunhikrishnan et al., 2004; Liu et al., 2005), and the import of pollution to Europe (Stohl and Trickl, 1999; Trickl et al., 2003; Stohl et al., 2003; Derwent et al., 2004, 2008), the US (Fiore et al., 2002, 2003; Lin et al., 2008), and Asia (Kunhikrishnan and Lawrence, 2004; Kunhikrishnan et al., 2006; Holloway et al., 2008).

Because these studies have used different models under different conditions with different experimental designs, it is difficult to compare the results to quantify the relative strength of ozone transport between different source and receptor regions (Task Force on Hemispheric Transport of Air Pollution, 2007). Few studies have considered multiple regions simultaneously in a common modeling framework, such that these influences can be compared directly. Fuglestvedt et al. (1999), Berntsen et al. (2005), and Naik et al. (2005) simulated changes in ozone precursor emissions from several world regions to assess their effects on tropospheric ozone and radiative climate forcing, but do not present results for surface air quality. Wild and Akimoto (2001) simulated the transport of ozone between three regions (USA, Europe, and East Asia) due to $10 \%$ increases in emissions of $\mathrm{NO}_{\mathrm{x}}$, $\mathrm{CO}$, and non-methane hydrocarbons from fossil fuel sources. Sudo and Akimoto (2007) used tagged tracer simulations to track the global distributions of ozone based on its region of formation, for many source regions globally. Hess and Lamarque (2007) similarly used tagged emissions to study the transport of ozone in the Northern Hemisphere $(\mathrm{NH})$ and its variability with the Arctic Oscillation. Recently, a large model intercomparison study was conducted, considering the transport of ozone among four source regions by simulating emission reductions (Task Force on Hemispheric Transport of Air Pollution, 2007; Fiore et al., 2009).

Here we consider nine world regions, and use a global model of atmospheric chemistry and transport to identify the strongest linkages, for surface ozone air quality, among all combinations of source and receptor regions. We estimate the influence of a $10 \%$ reduction in anthropogenic $\mathrm{NO}_{\mathrm{x}}$ emissions from each of these nine regions individually, considering the effects on surface ozone air quality within that region and in all other regions. Simultaneous 10\% reductions of anthropogenic $\mathrm{NO}_{\mathrm{x}}, \mathrm{NMVOC}$, and $\mathrm{CO}$ emissions are also simulated for three source regions. We present results for several surface ozone air quality metrics relevant for human health and regulatory purposes, including the population-weighted average ozone-season concentration in each region, and the average ozone-season concentration in populated subregions of interest. We further present the monthly distributions of inter-regional transport between source and receptor regions. Finally, we analyze changes in the export and production of ozone to explain differences in the sensitivity of ozone to changes in emissions from different source regions, and whether the transport of ozone itself or of the precursors of ozone is mainly responsible for inter-continental ozone influences.

These changes in emissions of $\mathrm{NO}_{\mathrm{x}}$ alone, or $\mathrm{NO}_{\mathrm{x}}$, NMVOCs, and CO together, cause changes in atmospheric $\mathrm{CH}_{4}$ concentrations through changes in the hydroxyl radical $(\mathrm{OH})$. Methane will respond slowly to changes in $\mathrm{OH}$, and in turn affect global ozone concentrations over the long lifetime of $\mathrm{CH}_{4}$, including at the surface (Wild et al., 2001; Naik et al., 2005; West et al., 2007). This paper presents only the direct short-term changes in ozone air quality due to emission reductions (i.e., $\mathrm{CH}_{4}$ concentrations are not allowed to adjust fully to changes in $\mathrm{OH}$ ); long-term changes in ozone air quality via $\mathrm{CH}_{4}$ are analyzed in the companion paper to this study (West et al., 2009), as are the consequences for premature human mortality due to exposure to ozone air pollution.

\section{Modeling methods}

We use the global modeling simulations presented by Naik et al. (2005), and analyze them here for their effects on surface ozone air quality. These simulations use the global chemistry-transport model MOZART-2, and a base simulation that corresponds to the early 1990s (Horowitz et al., 2003). Our simulations have a horizontal resolution of about $2.8^{\circ}$ by $2.8^{\circ}$, and 34 vertical levels. The simulations emphasize gas-phase photochemistry and while aerosols are not modeled explicitly, heterogeneous reactions of $\mathrm{N}_{2} \mathrm{O}_{5}$ and $\mathrm{NO}_{3}$ on sulfate aerosols are included. Emissions for the early 1990s were compiled by Horowitz et al. (2003) based on several global emissions sources, including EDGAR2.0 (Olivier et al., 1996). The model is driven by meteorological fields 
from the middle atmosphere version of the Community Climate Model (MACCM3), which are representative of current atmospheric transport conditions, and do not represent meteorology in a particular year. All simulations are conducted for 25 months, with results presented for the final 12 months.

Anthropogenic emissions of $\mathrm{NO}_{\mathrm{x}}$ at ground level are reduced by $10 \%$ in each of nine world regions (Fig. 1) individually, as described by Naik et al. (2005). Here, anthropogenic emissions include the combustion of fossil fuels and biofuels (among other sources), but do not include other forms of biomass burning. Reductions of $10 \%$ were selected to be small enough to represent the sensitivity to small changes in emissions, avoiding nonlinear chemical responses to large changes in $\mathrm{NO}_{\mathrm{x}}$, while being large enough to distinguish effects on long-range ozone transport (Wild and Akimoto, 2001). This approach differs from other studies that attempt to estimate the total impact of long-range transport by removing emissions entirely (e.g., Berntsen et al., 1999), or by tagging tracers (e.g., Sudo and Akimoto, 2007). Because of the importance of other anthropogenic precursors (NMVOCs, $\mathrm{CO}$, and $\mathrm{CH}_{4}$ ) and chemical nonlinearities, our estimates of the sensitivity of long-range ozone transport to $10 \%$ regional $\mathrm{NO}_{\mathrm{x}}$ reductions may not be good indicators of the total long-range transport among the regions. While Sudo and Akimoto (2007) consider many regions as in this study, they tag ozone based on the region in which the ozone (actually odd oxygen) is formed. In contrast, this study simulates the total effects of small changes in regional emissions, including ozone formed within the region and elsewhere, making a direct comparison with Sudo and Akimoto (2007) difficult. We model idealized controls on emissions of individual pollutants, whereas real actions to control emissions may affect multiple pollutants simultaneously, and may alter the spatial or temporal distributions of emissions. We also analyze simulations by Naik et al. (2005) of simultaneous $10 \%$ reductions in anthropogenic emissions of $\mathrm{NO}_{\mathrm{x}}$, NMVOCs and $\mathrm{CO}$ from three regions (NA, EU, and SE), to evaluate the effects of changes in NMVOC and CO emissions on surface ozone and long-range transport.

Table 1 presents the anthropogenic $\mathrm{NO}_{\mathrm{x}}$ emissions in each region in the base simulation. While our simulations represent emissions from the early 1990s, ozone precursor emissions have likely decreased since that time from NA, EU, and FSU, and are likely to have increased elsewhere (Schultz et al., 2007); increases may be most pronounced in East Asia, where $\mathrm{NO}_{\mathrm{x}}$ emissions are likely to have increased by more than 50\% (Richter et al., 2005; Zhang et al., 2008). Consequently, we likely underestimate the present-day influences of $10 \%$ reductions on long-range transport for rapidly developing regions such as East Asia. Changes in emissions since the early 1990s are likely less important for the changes in ozone per unit change in emissions, although such changes could affect the chemical regime and sensitivity of ozone formation to $\mathrm{NO}_{\mathrm{x}}$ and NMVOCs. The uncertainty in our estimates of long-range transport can be estimated by analyz-

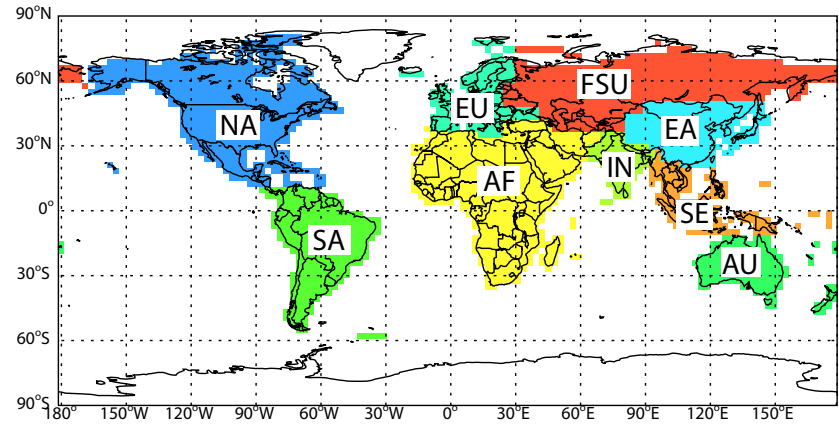

Fig. 1. Definitions for nine world regions.

ing the spread of several models in the HTAP experiments, which find an average coefficient of variation $(\sigma / \mu)$ of $38 \%$ for inter-regional ozone influences when reducing $\mathrm{NO}_{\mathrm{x}}$ emissions by $20 \%$, and of $31 \%$ when reducing $\mathrm{NO}_{\mathrm{x}}$, NMVOCs, $\mathrm{CO}$, and aerosols by $20 \%$ simultaneously (Task Force on Hemispheric Transport of Air Pollution, 2007; Fiore et al., 2009). Similarly, estimates of uncertainty can be derived from studies of the inter-annual variability of transport for particular regions. Duncan and Bey (2004) show little effect of meteorology on annual transport from Europe, and that inter-annual variability in transport is smaller than seasonal variability. For Liu et al. (2005), inter-annual variability is typically $30-40 \%$ of average transpacific transport, for passive tracers, with a maximum of $50 \%$. Finally, Li et al. (2002) show large influences of inter-annual variability in monthly average transatlantic transport, associated with transport events, but the effects on annual average transport, the main focus here, are likely smaller.

In Fig. 1, note that the Middle East is included as part of the Africa region, and Central America and the Caribbean are in the North America region. We present changes in surface ozone for several indicators, including the populationweighted ozone concentration. Population-weighting is done by multiplying the concentration and population of each grid cell, summing over all grid cells, and dividing by the total (regional or global) population, where the global distribution of population is taken from the LandScan database (Oak Ridge National Laboratory, 2005) for 2003, and mapped onto the MOZART-2 modeling grid.

\section{Model evaluation}

Results from the base simulation were compared previously with measurements of ozone and other chemical species aloft, suggesting that model predictions are generally in the range of measured concentrations (Horowitz et al., 2003). In Fig. 2, we compare the base simulation with surface measurements of ozone at non-urban sites from the Clean Air Status and Trends Network (CASTNET) in the 
Table 1. Total anthropogenic $\mathrm{NO}_{\mathrm{x}}$ emissions, population, and indicators of surface ozone concentration from the base simulation.

\begin{tabular}{lcccccc}
\hline \multicolumn{1}{c}{ Region } & $\begin{array}{c}\text { Anthropogenic } \\
\mathrm{NO}_{\mathrm{x}} \text { emissions } \\
\left(\mathrm{Tg} \mathrm{N} \mathrm{yr}^{-1}\right)\end{array}$ & $\begin{array}{c}\text { Annual average } \\
\mathrm{O}_{3} \text { (spatially- } \\
\text { weighted) }(\mathrm{ppb})\end{array}$ & $\begin{array}{c}\text { Population } \\
(\text { million })\end{array}$ & $\begin{array}{c}\text { Population- } \\
\text { weighted annual } \\
\text { average } \mathrm{O}_{3}(\mathrm{ppb})\end{array}$ & $\begin{array}{c}\text { 3-month population- } \\
\text { weighted average } \\
\mathrm{O}_{3}(\mathrm{ppb})^{\mathrm{a}}\end{array}$ & $\begin{array}{c}\text { 3-month } \\
\text { period with } \\
\text { highest } \mathrm{O}_{3}^{\mathrm{a}}\end{array}$ \\
\hline NA - North America & 8.0 & 35.2 & 496.0 & 35.5 & 42.6 & $\mathrm{May}-\mathrm{Jul}$ \\
EU - Europe & 4.8 & 34.9 & 543.6 & 32.0 & 40.4 & $\mathrm{Jun}-\mathrm{Aug}$ \\
FSU - Former Soviet Union & 2.5 & 31.6 & 249.1 & 31.0 & 39.5 & $\mathrm{Jun}-\mathrm{Aug}$ \\
AF - Africa & 2.0 & 35.3 & 1136.4 & 36.9 & 39.8 & $\mathrm{Mar}-\mathrm{May}$ \\
IN - India & 1.1 & 39.2 & 1382.8 & 41.0 & 48.1 & $\mathrm{Feb}-\mathrm{Apr}$ \\
EA - East Asia & 4.0 & 39.9 & 1531.9 & 37.7 & 43.7 & $\mathrm{Jul}-\mathrm{Sep}$ \\
SA - South America & 0.8 & 29.1 & 371.7 & 29.0 & 34.2 & Aug - Oct \\
SE - Southeast Asia & 0.7 & 23.2 & 558.0 & 28.1 & 31.2 & Dec - Feb \\
AU - Australia & 0.4 & 21.2 & 24.7 & 21.7 & 25.5 & Aug - Oct \\
Global & 24.2 & 26.0 & 6302.1 & 35.9 & & \\
\hline
\end{tabular}

a The consecutive three-month period with the highest population-weighted ozone concentration in the base simulation.
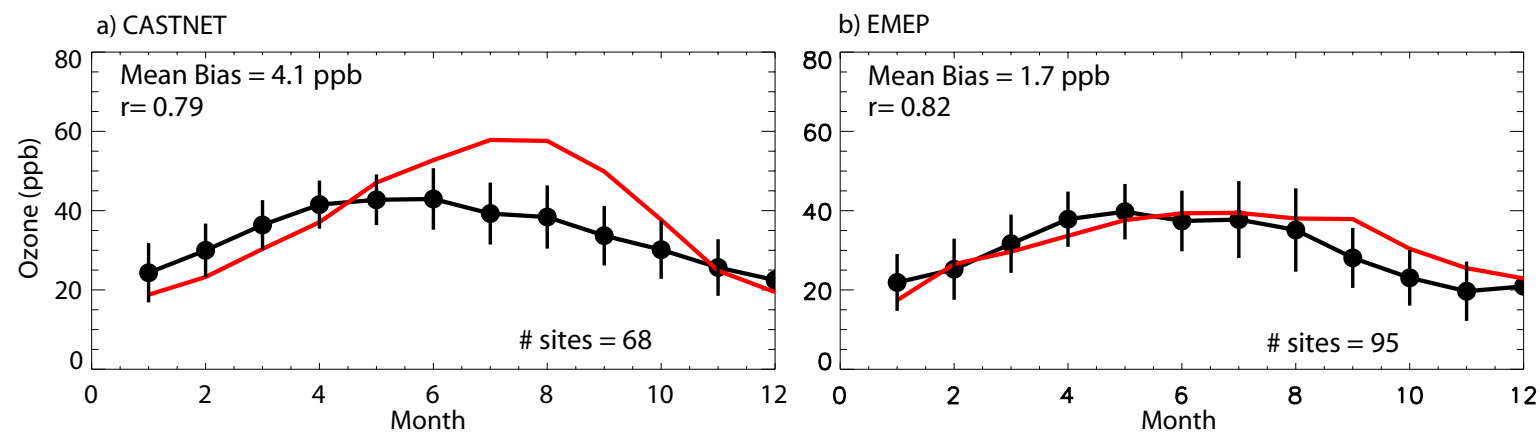

Fig. 2. Comparison of the monthly average modeled (red) and 1990 to 1994 average measured (black) surface ozone concentrations, averaging over (a) the CASTNET network in USA, and (b) the EMEP network in Europe. Errorbars on the observations show \pm 1 standard deviation among the multi-year averages for all sites.

USA (www.epa.gov/castnet) and the European Monitoring and Evaluation Programme (EMEP, www.nilu.no/projects/ ccc/emepdata.html). Because the simulation uses emissions from the early 1990s with meteorology that does not reflect a particular year, we compare the model prediction with the average of observations between 1990 and 1994. These results show that the model tends to overestimate the annual mean ozone, by $4.1 \mathrm{ppb}$ for CASTNET and $1.7 \mathrm{ppb}$ for EMEP, but that the CASTNET measurements are more substantially overestimated in summer. Analysis of biases at individual stations reveals some regional patterns; for example, the bias is greatest in the Southeastern US and over the Iberian Peninsula. We also compare the model results with measurements at seven remote stations from the NOAA Global Monitoring Division network (www.esrl.noaa.gov/gmd/dv/ftpdata.html), again showing that the model is biased high, by $5.8 \mathrm{ppb}$ for the annual average. However, the bias is particularly large at high altitude stations, and when two such stations are removed (Mauna Loa and Niwot Ridge), the bias for the remaining five stations is $2.8 \mathrm{ppb}$.
Table 1 shows surface ozone concentrations averaged within each region in the base simulation, for the annual average ozone, and the population-weighted average ozone during the ozone season (the consecutive three-month period with the highest average population-weighted ozone in that region). We analyze peak seasonal concentrations, as these are often of greatest regulatory concern, and by populationweighting the results, we emphasize polluted areas within the receptor region with a metric that is relevant for human health. These results identify IN (India) and EA (East Asia) as the regions with the highest modeled ozone concentrations in the base simulation.

\section{Results: short-term changes in ozone air quality}

Figure 3 shows the spatial distribution of the change in surface ozone concentrations due to $10 \%$ reductions in anthropogenic $\mathrm{NO}_{\mathrm{x}}$ emissions in each of the nine source regions, shown for the three-month period with the highest population-weighted ozone in each source region. The 

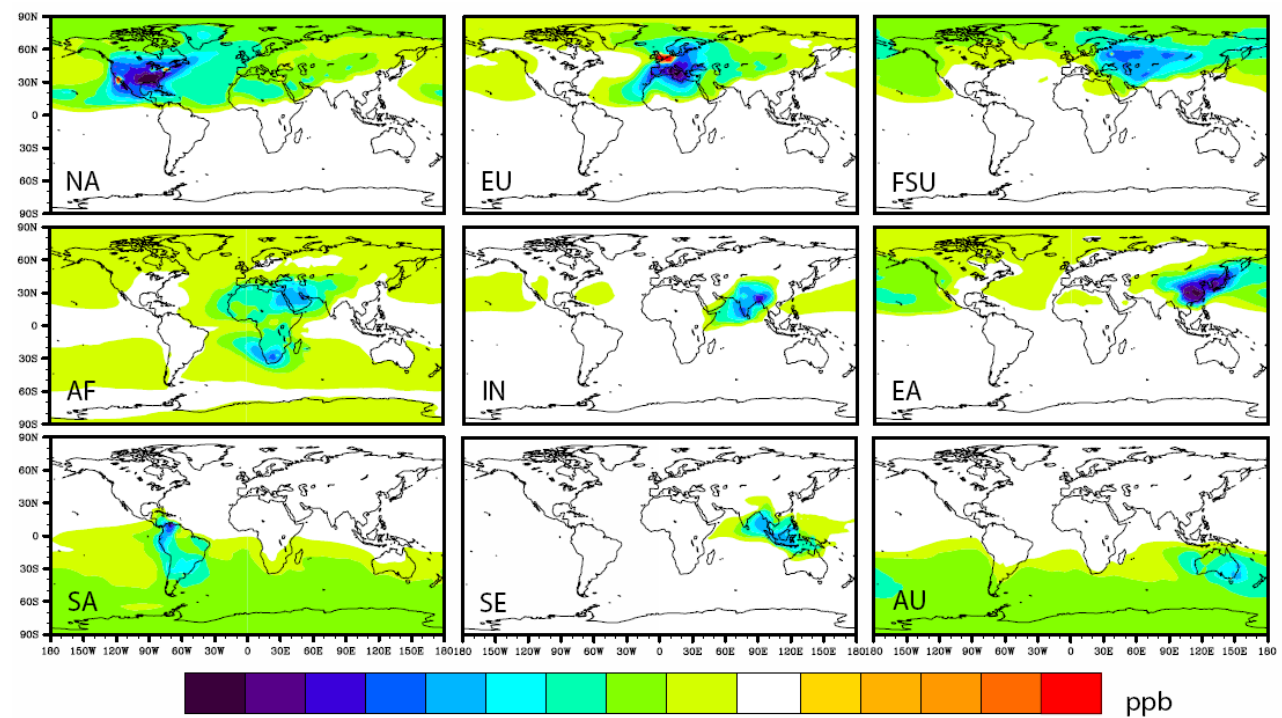

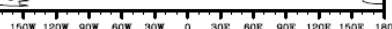

A

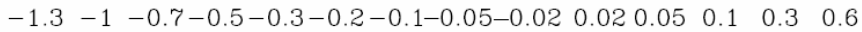

$\mathrm{ppb}$

Fig. 3. Change in 3-month average surface ozone concentration due to a $10 \%$ reduction in anthropogenic $\mathrm{NO}_{\mathrm{x}}$ emissions from each region, shown for the consecutive 3-month period in which the population-weighted ozone is highest in each source region (see Table 1).

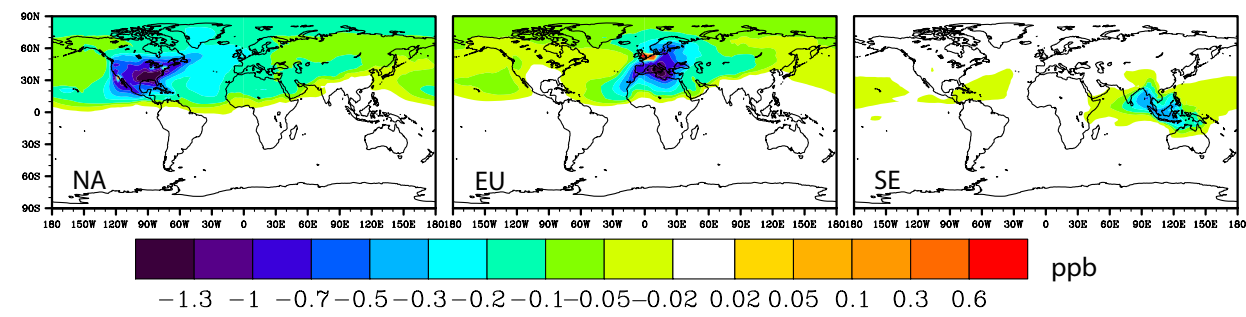

Fig. 4. As Fig. 3, but for the simulations where anthropogenic $\mathrm{NO}_{\mathrm{x}}, \mathrm{NMVOC}$, and $\mathrm{CO}$ emissions are reduced by $10 \%$.

results typically show surface ozone decreases greater than $0.2 \mathrm{ppb}$ in the source regions themselves, with smaller ozone decreases $(>0.02 \mathrm{ppb})$ observed over areas much larger than the source regions. Reductions $>1 \mathrm{ppb}$ are observed within the NA, EU, and EA source regions, with widespread influences throughout the $\mathrm{NH}$, as these regions have the greatest $\mathrm{NO}_{\mathrm{x}}$ emissions (and therefore the greatest decrease in $\mathrm{NO}_{\mathrm{x}}$ from the $10 \%$ reduction). Source regions in the Southern Hemisphere (SH) also have widespread effects on surface ozone in the $\mathrm{SH}$, despite relatively small total $\mathrm{NO}_{\mathrm{x}}$ emissions and small effects on ozone within the source regions, in agreement with previous results (Sudo and Akimoto, 2007). Transport between hemispheres is smaller than transport within each hemisphere, given the long interhemispheric mixing time scale ( $\sim 1$ year). The reductions in $\mathrm{NO}_{\mathrm{x}}$ emissions in IN and SE tend to affect surface ozone over a limited spatial extent, while the reductions in AF have widespread effects on ozone, as it has substantial emissions in both hemispheres. Figure 3 also shows that local $\mathrm{NO}_{\mathrm{x}}$ re- ductions cause surface ozone to increase over Northern Europe, Los Angeles, and New York; ozone production in these regions is strongly $\mathrm{NO}_{\mathrm{x}}$-saturated in the model, even in the peak ozone season, such that decreases in $\mathrm{NO}_{\mathrm{x}}$ emissions reduce the destruction of ozone by reaction with fresh NO emissions. Other global models also show that some of these regions are $\mathrm{NO}_{\mathrm{x}}$-saturated (Duncan et al., 2008). However, such local sensitivities to changes in emissions are uncertain in a global model, and differ among different global models (Fiore et al., 2009); these sensitivities are best determined using a local or regional model that has been thoroughly tested for local conditions. In addition, there are uncertainties associated with subgrid-scale chemical processing in urban regions, which may affect the export of ozone and its precursors from urban regions to the global model (e.g., Duncan and Chameides, 1998).

Table 2 shows the full source-receptor matrix for nine regions, for population-weighted ozone averaged over the 3month period with highest ozone in the receptor region. For all source regions, the $10 \%$ reduction in anthropogenic $\mathrm{NO}_{\mathrm{x}}$ 
Table 2. Source-receptor matrix of the change in 3-month population-weighted average ozone concentration (parts per trillion, ppt) in each receptor region due to $10 \% \mathrm{NO}_{\mathrm{x}}$ emission reductions in each source region (the 3-month period is defined for each receptor region in Table 1). Values underlined indicate the effect of a reduction in one region on itself (the diagonal). The nine highest inter-regional values are in bold.

\begin{tabular}{|c|c|c|c|c|c|c|c|c|c|c|}
\hline & & \multicolumn{9}{|c|}{ Receptor Region } \\
\hline & & NA & EU & FSU & $\mathrm{AF}$ & IN & EA & SA & SE & $\mathrm{AU}$ \\
\hline & NA & -512 & -63 & -46 & -44 & -44 & -8 & -11 & -10 & -3 \\
\hline & $\mathrm{EU}$ & $\overline{-8}$ & -194 & -184 & -73 & -13 & -9 & 1 & -3 & 1 \\
\hline & FSU & -14 & -55 & -401 & -16 & -16 & -27 & 0 & 0 & 0 \\
\hline Source & $\mathrm{AF}$ & -4 & -9 & -15 & -176 & $-\mathbf{5 0}$ & -1 & -8 & -8 & -17 \\
\hline \multirow{5}{*}{ Region } & IN & -4 & 0 & -2 & $\overline{-6}$ & -482 & -16 & -2 & -32 & -1 \\
\hline & EA & -16 & -7 & -16 & -6 & -6 & -930 & -1 & -105 & 0 \\
\hline & SA & -6 & 1 & 1 & -4 & -4 & $\overline{1}$ & -252 & -5 & -34 \\
\hline & SE & 0 & 2 & 1 & -2 & -15 & -38 & -9 & -265 & -11 \\
\hline & $\mathrm{AU}$ & 0 & 0 & 0 & -1 & 0 & 0 & -13 & $\overline{-3}$ & -179 \\
\hline
\end{tabular}

emissions has the greatest impact on ozone within that region. The largest inter-regional influences identified are from EU to FSU, EA to SE, and EU to AF, as these regions are contiguous. With these exceptions, intra-regional influences are generally larger than inter-regional influences by a factor of ten or more. The largest impacts, either within a source region or between regions, often result from the source regions $\mathrm{NA}, \mathrm{EU}$, and EA, as these have the largest $\mathrm{NO}_{\mathrm{x}}$ emissions.

While Table 2 highlights the regions with highest emissions, the regions with the greatest effects on ozone per unit change in $\mathrm{NO}_{\mathrm{x}}$ emissions are often in the tropics and $\mathrm{SH}$ (Table 3). The regions AU, IN, and SE have the largest effects per ton within their own regions, and some of the largest inter-regional influences are between regions in the tropics, in particular from SE to EA and SA to AU. The reasons for this enhanced sensitivity in the tropics and $\mathrm{SH}$ are explored in Sect. 4.3.

In Table 4 and Fig. 4, we show the changes in surface ozone for the three simulations where regional anthropogenic emissions of $\mathrm{NO}_{\mathrm{x}}, \mathrm{NMVOCs}$, and $\mathrm{CO}$ are reduced by $10 \%$ simultaneously. For the NA and EU reductions, the magnitudes of the surface ozone responses for both intra- and inter-regional influences, are comparable to those of Wild and Akimoto (2001). Comparing with Table 2, we see that adding the NMVOC and CO reductions causes only small additional decreases in ozone within the source regions NA and SE. However, reducing NMVOCs and CO more than doubles the ozone decrease for EU on itself, showing that the ozone formation in EU is strongly $\mathrm{NO}_{\mathrm{x}}$-saturated in the model. For all source-receptor pairs considered, reducing all three precursors decreases ozone more than when only $\mathrm{NO}_{\mathrm{x}}$ is reduced, with the ratio of results in Table 4 to Table 2 ranging from 1.3 to 3.0 (omitting the source-receptor pairs with decreases $<10 \mathrm{ppt}$ in Table 2). Reducing all three precursors in NA causes a greater relative influence on the receptor regions it influences most (1.7 to 1.9 times the results in Table 2 for the EU, FSU, AF, and IN receptor regions) than its effect on itself (1.3 times that in Table 2). Likewise, the ratio when reducing all three precursors in the SE source region is greater for the receptors it influences most (1.3 to 1.7 for IN, EA, and AU) than its effect on itself (1.1). These results suggest that the changes in emissions of NMVOCs and CO have important influences on long-range ozone transport, which will be analyzed further in Sect. 4.3.

We also calculate the source-receptor relationships for the annual average spatially-weighted change in ozone, a metric that would be used commonly in the atmospheric science literature. Comparing Tables and S1 and S2, see http://www.atmos-chem-phys.net/9/6077/2009/ acp-9-6077-2009-supplement.pdf, with Tables 2 and 4, respectively, the strongest source-receptor pairs are generally the same, but there are important quantitative differences. This suggests that the quantification of long-range transport can vary with the ozone concentration metric used. We likewise compare our results with the multi-model ensemble results of the HTAP model intercomparison exercise (Table $\mathrm{S} 3$ ), by using the same four receptor regions as defined by Fiore et al. (2009) and the same annual average spatiallyweighted indicators. In our case, however, the source regions (Fig. 1) differ from those of Fiore et al. (2009). In general, the inter-continental influences are smaller than the HTAP multi-model mean, indicating a lower sensitivity in our modeling; this is also the case in Table S4, where we normalize for the change in $\mathrm{NO}_{\mathrm{x}}$ emissions, and Table S5 for simultaneous $\mathrm{NO}_{\mathrm{x}}, \mathrm{NMVOC}$, and $\mathrm{CO}$ reductions. In addition to different source region definitions, this study used different meteorology and emissions for the early 1990s rather than for 2001. In the HTAP model intercomparison, with all models simulating 2001 conditions, MOZART-2 also shows a relatively low sensitivity of ozone and its long-range transport to changes in emissions. 
Table 3. Normalized source-receptor matrix showing the change in 3-month population-weighted average ozone (Table 2) per unit change in $\mathrm{NO}_{\mathrm{x}}$ emissions $\left(\mathrm{ppb}\left(\mathrm{TgN} \mathrm{yr}^{-1}\right)^{-1}\right)$. Note that negative ozone changes divided by the negative change in $\mathrm{NO}_{\mathrm{x}}$ emissions gives mainly positive values here.

\begin{tabular}{rlrrrrrrrrr}
\hline & \multicolumn{1}{c}{ N } & NA & EU & FSU & AF & IN & EA & SA & SE & AU \\
\hline & NA & $\underline{0.64}$ & 0.08 & 0.06 & 0.06 & 0.05 & 0.01 & 0.01 & 0.01 & 0.00 \\
& EU & 0.02 & $\underline{0.40}$ & $\mathbf{0 . 3 8}$ & 0.15 & 0.03 & 0.02 & 0.00 & 0.01 & 0.00 \\
& FSU & 0.06 & $\mathbf{0 . 2 2}$ & $\underline{1.62}$ & 0.07 & 0.06 & 0.11 & 0.00 & 0.00 & 0.00 \\
Rource & AF & 0.02 & 0.04 & 0.07 & $\underline{0.89}$ & $\mathbf{0 . 2 5}$ & 0.00 & 0.04 & 0.04 & 0.08 \\
& IN & 0.04 & 0.00 & 0.02 & 0.05 & $\underline{4.19}$ & 0.14 & 0.02 & $\mathbf{0 . 2 8}$ & 0.01 \\
& EA & 0.04 & 0.02 & 0.04 & 0.02 & 0.02 & $\underline{2.33}$ & 0.00 & $\mathbf{0 . 2 6}$ & 0.00 \\
& SA & 0.07 & -0.02 & -0.01 & 0.05 & 0.05 & -0.01 & $\underline{3.07}$ & 0.06 & $\mathbf{0 . 4 1}$ \\
& SE & 0.00 & -0.02 & -0.01 & 0.04 & $\mathbf{0 . 2 3}$ & $\mathbf{0 . 5 8}$ & $\underline{0.13}$ & $\underline{4.05}$ & 0.16 \\
& AU & -0.01 & -0.01 & -0.01 & 0.02 & 0.02 & -0.01 & $\mathbf{0 . 3 4}$ & 0.08 & $\underline{4.70}$ \\
\hline
\end{tabular}

Table 4. Source-receptor matrix for the simulations where anthropogenic emissions of $\mathrm{NO}_{\mathrm{x}}, \mathrm{NMVOCs}$, and CO are all reduced by $10 \%$ (for the 3-month population-weighted average ozone, in ppt).

\begin{tabular}{llrrrrrrrrr}
\hline & & \multicolumn{1}{c}{ Receptor Region } \\
& & NA & EU & FSU & AF & IN & EA & SA & SE & AU \\
\hline Source & NA & -668 & $-\mathbf{1 1 3}$ & $-\mathbf{7 7}$ & $\mathbf{- 8 6}$ & $\mathbf{- 8 0}$ & -17 & -16 & -29 & -6 \\
Region & EU & -29 & -407 & $-\mathbf{2 4 0}$ & $-\mathbf{1 3 4}$ & -40 & -18 & -2 & -21 & -1 \\
& SE & -4 & -1 & -2 & -8 & -25 & -47 & -15 & $\underline{-300}$ & -17 \\
\hline
\end{tabular}

\subsection{Seasonal cycle of changes in long-range ozone transport}

In Fig. 5, we analyze the monthly surface ozone response to the regional $10 \% \mathrm{NO}_{\mathrm{x}}$ reductions averaged within each receptor region. Considering NA as a receptor, the $10 \% \mathrm{NO}_{\mathrm{x}}$ reduction in EA causes the greatest reduction in ozone in October and November, with another peak in April, but has a substantially smaller influence during the summer when ozone is highest in NA. This seasonal distribution of transpacific transport is well documented, although other studies that used different meteorology have identified spring as the period of greatest transport (Wild and Akimoto, 2001; Liu et al., 2005). Similarly, the influence of NA on EU is maximum in spring and fall, in agreement with previous results (Li et al., 2002). AF is substantially influenced by the $\mathrm{NO}_{\mathrm{x}}$ reductions in EU and FSU during April through August, while the influence of NA is relatively uniform throughout the year.

In IN during the period of highest ozone (February through April), ozone responds most strongly to the $\mathrm{NO}_{\mathrm{x}}$ reduction in NA and AF. During the monsoon season of June through September, long-range influences on ozone in IN are small. Following the monsoon season, however, SE and EA have substantial influences on ozone in IN, as winds during these months are predominantly from the Northeast and East. SE likewise experiences the greatest influence from EA during this period. EA is influenced most strongly, during its pe- riod of highest ozone, by the $\mathrm{NO}_{\mathrm{x}}$ reductions in $\mathrm{SE}$ and $\mathrm{FSU}$, while the influences of NA, EU, and AF are higher in other seasons.

Figure 6 shows the monthly effects of $\mathrm{NO}_{\mathrm{x}}$ reductions on ozone in the source regions themselves, with influences that are typically much larger than the inter-regional influences in Fig. 5. Figure 6 shows a clear summer maximum in the influence of $\mathrm{NO}_{\mathrm{x}}$ reductions within the source regions in the temperate NH (NA, EU, FSU, and EA). While ozone decreases within these source regions in the NH summer, it increases in the $\mathrm{NH}$ winter due to local titration with $\mathrm{NO}$ emissions, in agreement with other model results (Wild and Akimoto, 2001; Duncan et al., 2008). This winter increase in ozone is often weaker when considering inter-regional transport (Fig. 5). The $\mathrm{NO}_{\mathrm{x}}$ reductions in EU cause a strong increase in ozone in the FSU in winter, but relatively smaller increases in winter in NA, AF, and EA.

Despite the fact that $\mathrm{NO}_{\mathrm{x}}$ reductions in NA cause the greatest within-region reductions in summer (Fig. 6), its influences on EU and FSU are greater in the NH spring and fall, and the influences on AF, IN, EA, and SA are actually greatest in the NH winter. This could be due to conditions more conducive to transport outside of the NH summer, as well as the longer lifetime of ozone in the colder seasons. Likewise, the $\mathrm{NO}_{\mathrm{x}}$ reductions in EA have large influences on ozone in NA, EU, IN, and SE in October and November, after the period of the greatest influence within 

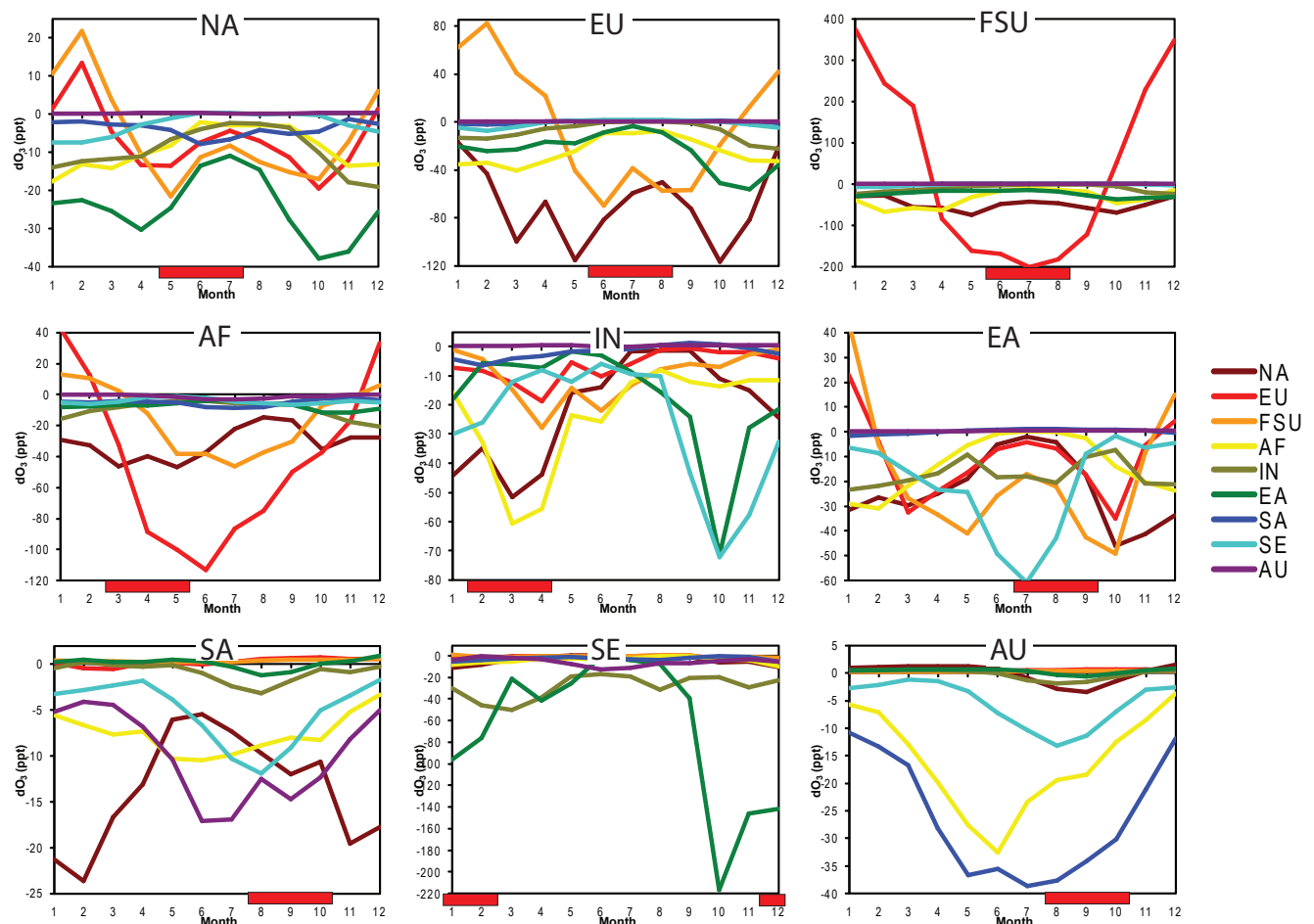

Fig. 5. Monthly influences of $10 \%$ regional $\mathrm{NO}_{\mathrm{x}}$ reductions, where each panel depicts the influences of several source regions on a receptor region, for the monthly-average population-weighted ozone concentration. The effects of source regions on themselves are omitted (see Fig. 6), as these are typically much larger than the inter-regional influences. Red bars on the horizontal axis indicate the three-month period when the modeled population-weighted average ozone is highest in each receptor region. Note that the vertical axes differ in each panel.

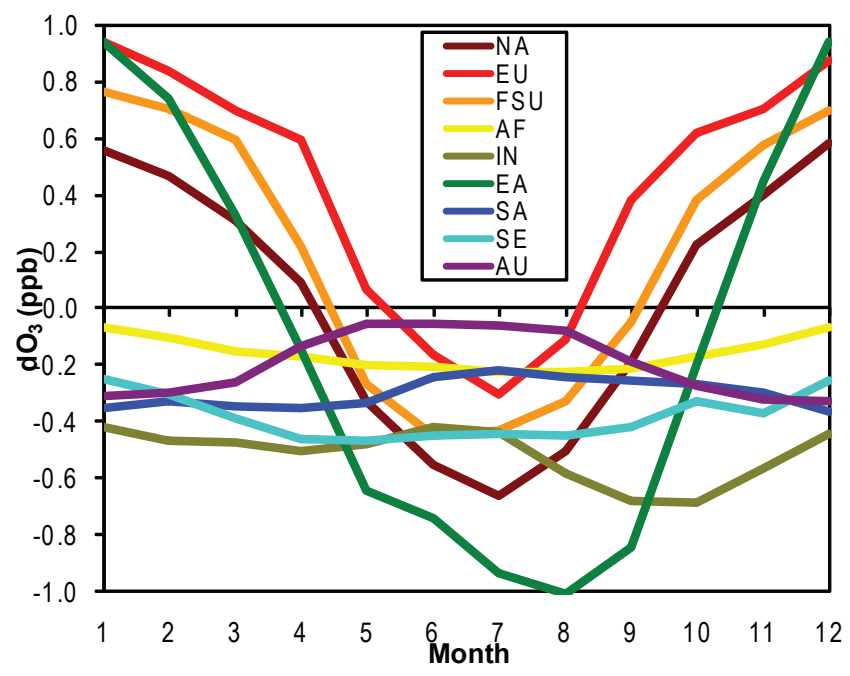

Fig. 6. Monthly influences of $10 \%$ regional $\mathrm{NO}_{\mathrm{x}}$ reductions on ozone in the source regions themselves, for the monthly-average population-weighted ozone concentration.
EA. This is also the period in which EA is most influenced by $\mathrm{NO}_{\mathrm{x}}$ reductions from other source regions in the $\mathrm{NH}$ (NA, EU, FSU), suggesting that the meteorological conditions that favor long-range transport from EA, including less stagnation and greater vertical mixing, also cause greater import of ozone from elsewhere in the NH. For the source regions NA and EA, as well as for EU and FSU for some receptor regions, these results show that while the greatest changes in ozone production occur in the summer, the conditions for transport to other $\mathrm{NH}$ receptors are more prevalent at other times of year.

These monthly influences are quantified in Table S6. While Table 2 shows the influence on ozone during the threemonth period when ozone is highest at the receptor, Table S6 shows the maximum three-month average influence for each source-receptor pair. Here, for example, the influence of the $\mathrm{NO}_{\mathrm{x}}$ reduction in EA on several receptor regions in the $\mathrm{NH}$ is substantially greater than shown in Table 2 , because the period of maximum influence does not coincide with the period of highest ozone in the receptor region. 


\subsection{Effects of $\mathrm{NO}_{\mathrm{x}}$ reductions on populated subregions of interest}

In addition to evaluating the impacts of regional $\mathrm{NO}_{\mathrm{x}}$ reductions on ozone over continental regions, we can also consider effects using smaller subregions as receptors. Table 5 shows the changes in the three-month average ozone in selected subregions. We select subregions that have high population densities, significant ozone pollution, or lie close to the border of different regions to illustrate inter-regional transport. We define large subregions using 3 by 3 grid cells (roughly $8.4^{\circ}$ by $8.4^{\circ}$, see Fig. S1), larger than any single metropoli$\tan$ area, so that the results are not strongly influenced by local chemistry in the urban region, which is uncertain in the global model, while inter-continental influences are captured.

In Table 5, the $\mathrm{NO}_{\mathrm{x}}$ reduction in EA has a greater influence on Los Angeles than on Toronto or the populationweighted average for NA (Table 2). Likewise, the $\mathrm{NO}_{\mathrm{x}}$ reduction in NA has a stronger influence on London than populated subregions further east. Reductions in $\mathrm{NO}_{\mathrm{x}}$ from $\mathrm{EU}$ increase ozone in London, as ozone formation in this region is strongly $\mathrm{NO}_{\mathrm{x}}$-saturated in the model (Fig. 3). Athens, Moscow, Cairo, and Tehran are all influenced strongly by $\mathrm{NO}_{\mathrm{x}}$ reductions in the regions $\mathrm{EU}, \mathrm{FSU}$, and $\mathrm{AF}$, illustrating the strong influences that these regions have on one another. Bangkok and Manila are strongly influenced by EA, although Jakarta is not, showing the lack of transport across the equator. For subregions in IN, reductions in $\mathrm{NO}_{\mathrm{x}}$ emissions in $\mathrm{SE}$ and EA strongly reduce ozone in Chennai, as these regions mainly affect ozone in Southern India. Delhi, on the other hand, shows very little influence from emissions from SE, but is influenced more by the reductions in AF and NA.

If we normalize the influences on ozone per unit change in $\mathrm{NO}_{\mathrm{x}}$ emissions, as in Table 3 (see Table S7), we see that $\mathrm{NO}_{\mathrm{x}}$ reductions from EA are on average about $20 \%$ as effective per ton at improving ozone air quality in Los Angeles, as reductions in NA. Likewise, $\mathrm{NO}_{\mathrm{x}}$ reductions from $\mathrm{EU}$ are on average about $20 \%$ as effective per ton at improving ozone air quality in Cairo, as reductions in AF. For this comparison, we compare the effects of $10 \% \mathrm{NO}_{\mathrm{x}}$ emission reductions over the large continental regions. Had we assessed the effect of $\mathrm{NO}_{\mathrm{x}}$ reductions only in the Cairo area, for example, they would presumably be more effective per ton at improving ozone in Cairo than reductions that take place over all of $\mathrm{AF}$ (but depending on the local chemical response), and the effectiveness of $\mathrm{NO}_{\mathrm{x}}$ reductions in $\mathrm{EU}$ would be less than $20 \%$ as effective as reductions in the Cairo area itself.

Table $\mathrm{S} 8$ shows these effects on subregions for the simulations in which $\mathrm{NO}_{\mathrm{x}}, \mathrm{NMVOCs}$, and $\mathrm{CO}$ are reduced simultaneously. For all source-receptor influences shown, the results are greater (more negative) than in Table 5, in agreement with the relationships between Tables 2 and 4 .

\subsection{Changes in ozone production and export}

In Table 3, surface ozone is more sensitive to changes in emissions from tropical and $\mathrm{SH}$ regions than from temperate $\mathrm{NH}$ regions. Here we analyze changes in the total production and export of ozone and precursors to explain this enhanced sensitivity. We further use this analysis to assess whether the transport of ozone or of its precursors is more important for inter-continental ozone transport.

Consistent with Table 3, Table 6 shows that the change in the tropospheric ozone burden (defined as below the "chemical tropopause" of $150 \mathrm{ppb}$ ozone in the base simulation) per unit change in $\mathrm{NO}_{\mathrm{x}}$ emissions is greatest for $\mathrm{NO}_{\mathrm{x}}$ reductions from SE, SA, and AU. The large difference in sensitivity between temperate regions and those in the tropics and SH agrees with previous results (Fuglestvedt et al., 1999; Berntsen et al., 2005; Naik et al., 2005).

One explanation for the greater sensitivity in tropical source regions is the year-round photochemical activity in the tropics. In addition, global emissions of $\mathrm{NO}_{\mathrm{x}}$ are strongly concentrated in the industrialized source regions of the temperate $\mathrm{NH}$, with $80 \%$ of global anthropogenic emissions in NA, EU, FSU, and EA (Table 1). With a much lower density of $\mathrm{NO}_{\mathrm{x}}$ emissions in tropical regions and the $\mathrm{SH}$, ozone concentrations would be expected to be more sensitive to changes in $\mathrm{NO}_{\mathrm{x}}$ emissions, due to the nonlinearity of ozone chemistry with respect to its precursors. Furthermore, active convection in tropical regions can transport ozone and its precursors more effectively to the upper troposphere, thereby increasing their lifetimes and the ability of precursors to produce ozone. While greater water vapor concentrations (causing greater loss of ozone by reactions of $\mathrm{O}\left({ }^{1} \mathrm{D}\right)+\mathrm{H}_{2} \mathrm{O}$, $\mathrm{O}_{3}+\mathrm{OH}$, and $\mathrm{O}_{3}+\mathrm{HO}_{2}$ ) and convective mixing (bringing ozone into contact with vegetated surfaces) can decrease the ozone lifetime in the tropics (Lawrence et al., 2003), these processes are clearly not dominant in the model since Table 6 shows greater sensitivity.

In Table 6, the decrease in regional $\mathrm{NO}_{\mathrm{x}}$ emissions in each region decreases ozone production, and increases the global average ozone lifetime. Because the global ozone burden decreases for all source regions, we can infer that the change in production dominates over the increase in lifetime, which would tend to increase ozone. In Table 6, the greater change in ozone burden per unit change in $\mathrm{NO}_{\mathrm{x}}$ emissions for regions in the tropics and SH is partially explained by the greater change in ozone production per unit emissions, with SE having the greatest change for both quantities. Table 6 also shows that SE has by far the highest fraction of the change in ozone production (35\%) occurring in the upper troposphere (above $469 \mathrm{mb}$ ), with high values for other regions near the equator (IN and SA), suggesting greater vertical transport of precursors. Likewise, the ozone lifetime diagnosed from the change in regional emissions is greatest from tropical and $\mathrm{SH}$ regions, perhaps due partly to the greater fraction of ozone production in the upper troposphere. Even for SE, however, 
Table 5. Change in 3-month average ozone (ppt) in selected receptor subregions due to $10 \% \mathrm{NO}_{\mathrm{x}}$ reductions from source regions. Ozone changes are area-weighted within the $8.4^{\circ} \times 8.4^{\circ}$ receptor regions, and reported for the three months with highest ozone in the base simulation (in parenthesis). See supporting information for region definitions and results per unit emission reduction.

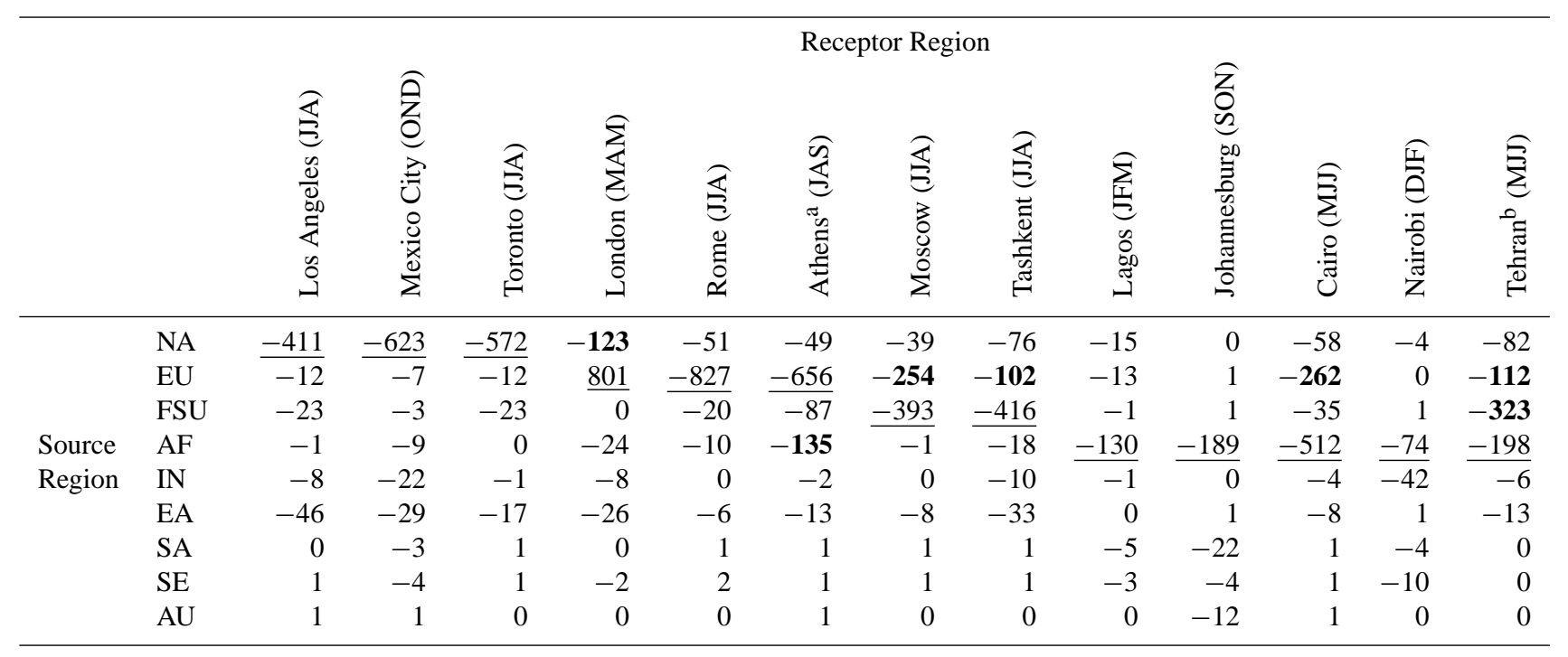

Table 5. Continued.

\begin{tabular}{|c|c|c|c|c|c|c|c|c|c|c|c|c|c|c|}
\hline & & \multicolumn{13}{|c|}{ Receptor Region } \\
\hline & & 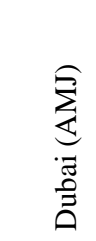 & 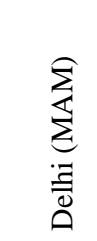 & 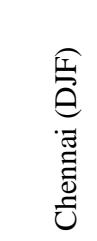 & 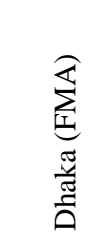 & $\begin{array}{l}\hat{z} \\
0 \\
00 \\
\overline{0} \\
0 \\
00 \\
0 \\
0\end{array}$ & 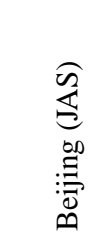 & 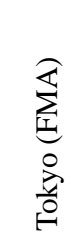 & 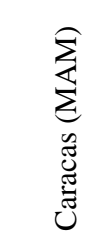 & 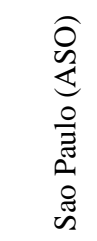 & 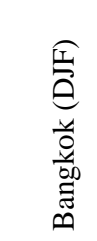 & 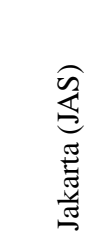 & 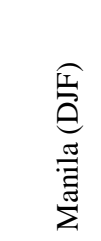 & 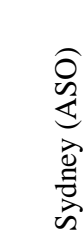 \\
\hline & NA & -71 & -71 & -15 & -25 & -28 & -17 & -62 & -95 & -2 & -14 & -3 & -33 & -2 \\
\hline & EU & -65 & -24 & -1 & -3 & -14 & -20 & -41 & -4 & 1 & -5 & 1 & -10 & 1 \\
\hline & FSU & -67 & -38 & 0 & -2 & -10 & -62 & -27 & 0 & 0 & -1 & 1 & -1 & 0 \\
\hline Source & $\mathrm{AF}$ & -356 & -83 & -5 & -19 & -14 & -1 & -40 & -10 & -8 & -7 & -3 & -17 & -17 \\
\hline \multirow{5}{*}{ Region } & IN & -27 & -363 & -319 & -763 & -25 & -7 & -15 & -4 & -1 & -21 & -2 & -37 & -1 \\
\hline & EA & -10 & $\overline{-10}$ & $\overline{-45}$ & $\overline{-5}$ & -583 & $\underline{-810}$ & $\underline{177}$ & -3 & 0 & -232 & -1 & -134 & 0 \\
\hline & SA & -2 & -3 & -7 & -4 & 0 & 1 & $\overline{-1}$ & -199 & -215 & -3 & -12 & -6 & -32 \\
\hline & SE & -2 & -5 & -106 & -34 & -7 & -5 & -6 & -4 & -8 & -243 & -228 & -89 & -10 \\
\hline & $\mathrm{AU}$ & 0 & 0 & 0 & 0 & 1 & 0 & 0 & 0 & -23 & 0 & -26 & 0 & -300 \\
\hline
\end{tabular}

a The region defined for Athens lies mainly in EU, and partly in AF.

$\mathrm{b}$ The region defined for Tehran lies mainly in AF, and partly in FSU.

the majority of the change in ozone production occurs in the lower troposphere. All regions also have a majority of the change in ozone production below the top of the mixing layer (taken as $744 \mathrm{mb}$ ), except for SE (with $52 \%$ above).

In Table 7 , we analyze changes in the tropospheric $\mathrm{NO}_{\mathrm{y}}$ burden as an indicator of the transport of $\mathrm{NO}_{\mathrm{x}}$ and its oxidation products that can lead to ozone formation. The tropical and $\mathrm{SH}$ regions have the greatest change in $\mathrm{NO}_{\mathrm{y}}$ burden per unit change in emissions, leading to large decreases in ozone production. The fraction of the change in $\mathrm{NO}_{\mathrm{y}}$ burden in the upper troposphere is also greatest for these same regions, as is the $\mathrm{NO}_{\mathrm{y}}$ lifetime diagnosed from the change in emissions. The greater vertical convection for tropical regions is therefore important in transporting ozone and $\mathrm{NO}_{\mathrm{y}}$ to the upper troposphere, which is expected to contribute to 
Table 6. Changes in global annual mean tropospheric $\mathrm{O}_{3}$ burden $\left(\mathrm{B}_{\mathrm{O} 3}\right)$, global annual $\mathrm{O}_{3}$ production $\left(\mathrm{P}_{\mathrm{O} 3}\right)$ and net export from the source region $\left(\mathrm{X}_{\mathrm{O} 3}\right)$, also shown per unit change in $\mathrm{NO}_{\mathrm{x}}$ emissions $\left(\mathrm{E}_{\mathrm{NOx}}\right)$, the $\mathrm{O}_{3}$ lifetime, and fractions of these quantities above the source region and in the upper troposphere.

\begin{tabular}{lccccccc}
\hline & $\begin{array}{c}\Delta \mathrm{B}_{\mathrm{O} 3} \\
\left(\mathrm{TgO}_{3}\right)\end{array}$ & $\begin{array}{c}\Delta \mathrm{B}_{\mathrm{O} 3} / \\
\Delta \mathrm{E}_{\mathrm{NOx}} \\
\left(\mathrm{TgO}_{3}\right. \\
\left.\left(\mathrm{TgN} \mathrm{yr}^{-1}\right)^{-1}\right)\end{array}$ & $\begin{array}{c}\Delta \mathrm{P}_{\mathrm{O} 3} \\
\left(\mathrm{TgO}_{3} \mathrm{yr}^{-1}\right)\end{array}$ & $\begin{array}{c}\Delta \mathrm{P}_{\mathrm{O} 3} / \\
\Delta \mathrm{E}_{\mathrm{NOx}} \\
\left(\mathrm{TgO}_{3} \mathrm{yr}^{-1}\right. \\
\left.\left(\mathrm{TgN} \mathrm{yr}^{-1}\right)^{-1}\right)\end{array}$ & $\begin{array}{c}\text { Regional } \mathrm{O}_{3} \\
\text { lifetime } \\
\left(\Delta \mathrm{B}_{\mathrm{O} 3} /\right. \\
\left.\Delta \mathrm{P}_{\mathrm{O} 3}\right) \\
(\text { days })^{\mathrm{a}}\end{array}$ & $\begin{array}{c}\text { Global } \Delta \mathrm{O}_{3} \\
\text { lifetime } \\
(\mathrm{B} / \mathrm{P}) \\
(\text { days })^{\mathrm{b}}\end{array}$ & $\begin{array}{c}\mathrm{Global}^{\mathrm{b}} \mathrm{O}_{3} \\
\text { lifetime/ }\end{array}$ \\
\hline $\mathrm{NA}$ & -0.464 & 0.58 & -14.50 & 18.2 & 11.7 & 0.037 & $\begin{array}{c}\Delta \mathrm{E}_{\mathrm{NOx}} \\
(\text { days } \\
\left.\left(\mathrm{TgN} \mathrm{yr}^{-1}\right)^{-1}\right)\end{array}$ \\
$\mathrm{EU}$ & -0.091 & 0.19 & -4.77 & 9.9 & 7.0 & 0.017 & -0.046 \\
$\mathrm{FSU}$ & -0.069 & 0.28 & -3.62 & 14.7 & 7.0 & 0.013 & -0.034 \\
$\mathrm{AF}$ & -0.241 & 1.21 & -7.32 & 36.9 & 12.0 & 0.018 & -0.090 \\
$\mathrm{IN}$ & -0.193 & 1.68 & -4.69 & 40.9 & 15.0 & 0.009 & -0.076 \\
$\mathrm{EA}$ & -0.247 & 0.62 & -7.52 & 18.9 & 12.0 & 0.019 & -0.047 \\
$\mathrm{SA}$ & -0.266 & 3.25 & -6.43 & 78.5 & 15.1 & 0.012 & -0.144 \\
$\mathrm{SE}$ & -0.304 & 4.65 & -5.93 & 90.6 & 18.7 & 0.007 & -0.100 \\
$\mathrm{AU}$ & -0.120 & 3.14 & -2.55 & 66.7 & 17.2 & 0.004 & -0.094 \\
\hline
\end{tabular}

Table 6. Continued.

\begin{tabular}{lccccc}
\hline & $\begin{array}{c}\text { Fraction } \\
\text { of global } \\
\Delta \mathrm{B}_{\mathrm{O} 3} \text { above } \\
\text { source region }\end{array}$ & $\begin{array}{c}\text { Fraction } \\
\text { of global } \\
\Delta \mathrm{P}_{\mathrm{O} 3} \text { above } \\
\text { source region }\end{array}$ & $\begin{array}{c}\text { Fraction } \\
\text { of global } \\
\Delta \mathrm{P}_{\mathrm{O} 3} \text { above } \\
469 \mathrm{mb}\end{array}$ & $\begin{array}{c}\Delta \mathrm{X}_{\mathrm{O} 3} \text { from } \\
\text { source } \\
\text { region } \\
\left(\mathrm{TgO}_{3} \mathrm{yr}^{-1}\right)\end{array}$ & $\begin{array}{c}\Delta \mathrm{P}_{\mathrm{O} 3} \\
\text { outside of } \\
\text { source region } \\
\left(\mathrm{TgO}_{3} \mathrm{yr}^{-1}\right)\end{array}$ \\
\hline $\mathrm{NA}$ & 0.205 & 0.755 & 0.155 & -3.51 & -3.55 \\
$\mathrm{EU}$ & 0.106 & 0.631 & 0.068 & -0.73 & -1.76 \\
$\mathrm{FSU}$ & 0.259 & 0.799 & 0.041 & -0.82 & -0.73 \\
$\mathrm{AF}$ & 0.255 & 0.870 & 0.102 & -2.16 & -0.95 \\
$\mathrm{IN}$ & 0.112 & 0.803 & 0.213 & -1.85 & -0.93 \\
$\mathrm{EA}$ & 0.157 & 0.809 & 0.112 & -2.25 & -1.43 \\
$\mathrm{SA}$ & 0.177 & 0.749 & 0.189 & -1.92 & -1.61 \\
$\mathrm{SE}$ & 0.140 & 0.799 & 0.355 & -2.39 & -1.19 \\
$\mathrm{AU}$ & 0.076 & 0.511 & 0.086 & -0.54 & -1.25 \\
\hline
\end{tabular}

${ }^{\text {a }}$ We use $\Delta \mathrm{B}_{\mathrm{O} 3} / \Delta \mathrm{P}_{\mathrm{O} 3}$ to diagnose the ozone lifetime associated with changes in regional $\mathrm{NO}_{\mathrm{x}}$ emissions, assuming it is not changed significantly by the small $\mathrm{NO}_{\mathrm{x}}$ emission change.

$\mathrm{b}$ The global ozone lifetime $(\mathrm{B} / \mathrm{P})$ is calculated to be 24.19 days in the base simulation, and changes in this lifetime due to regional $\mathrm{NO}_{\mathrm{x}}$ emission changes are reported.

a longer lifetime of ozone and enhance the ozone production per unit change in $\mathrm{NO}_{\mathrm{x}}$ emissions.

Because most of the change in ozone production occurs in the lower troposphere, we conclude that the enhanced ozone sensitivity per unit $\mathrm{NO}_{\mathrm{x}}$ emissions for tropical and $\mathrm{SH}$ regions is mainly due to greater sensitivity to $\mathrm{NO}_{\mathrm{x}}$ in the lower troposphere, and only partially due to the greater vertical transport. For surface ozone air quality, production in the lower troposphere is expected to be even more important than for the tropospheric burden. This result is clarified by analyzing $\mathrm{AU}$, the only region entirely in the $\mathrm{SH}$. While AU has a large change in ozone burden per unit change in $\mathrm{NO}_{\mathrm{x}}$ emissions, the fractions of the changes in ozone production and $\mathrm{NO}_{\mathrm{y}}$ burden occurring in the upper troposphere are relatively small, as the majority of AU emissions are south of the tropical region of high convective activity. The large sensitivity to changes in $\mathrm{NO}_{\mathrm{x}}$ for $\mathrm{AU}$ is therefore due to the relative lack of $\mathrm{NO}_{\mathrm{x}}$ and greater sensitivity of ozone production to $\mathrm{NO}_{\mathrm{x}}$ in the $\mathrm{SH}$, mainly in the lower troposphere. Note that while much of $\mathrm{AF}$ is in the tropics, the majority of $\mathrm{NO}_{\mathrm{x}}$ emissions are outside of the tropics in the Middle East or in South Africa, where less is transported to the upper troposphere.

Previous studies have emphasized that while vertical transport is not very important for the export of pollution from North America and Europe annually, it is important during the summer (Li et al., 2002; Duncan and Bey, 2004), and especially for transport from East Asia in the seasons 
Table 7. Changes in global annual average $\mathrm{NO}_{\mathrm{y}}$ burdens, globally and outside of the source region, also shown per unit change in $\mathrm{NO}_{\mathrm{x}}$ emissions.

\begin{tabular}{lcccccc}
\hline & $\begin{array}{c}\Delta \mathrm{B}_{\mathrm{NOy}} \\
(\mathrm{GgN})\end{array}$ & $\begin{array}{c}\Delta \mathrm{B}_{\mathrm{NOy}} / \Delta \mathrm{E}_{\mathrm{NOx}} \\
\left(\mathrm{GgN}\left(\mathrm{TgN} \mathrm{yr}^{-1}\right)^{-1}\right)^{\mathrm{a}}\end{array}$ & $\begin{array}{c}\Delta \mathrm{B}_{\mathrm{NOy}} \\
\text { outside of } \\
\text { source region } \\
(\mathrm{GgN})\end{array}$ & $\begin{array}{c}\Delta \mathrm{B}_{\mathrm{NOy}} / \Delta \mathrm{E}_{\mathrm{NOx}} \\
\text { outside of } \\
\text { source region } \\
\left(\mathrm{GgN}\left(\mathrm{TgN} \mathrm{yr}^{-1}\right)^{-1}\right)\end{array}$ & $\begin{array}{c}\text { Fraction of } \\
\Delta \mathrm{B}_{\mathrm{NOy}} \text { outside } \\
\text { of source } \\
\text { region }\end{array}$ & $\begin{array}{c}\text { Fraction of } \\
\Delta \mathrm{B}_{\mathrm{NOy}} \text { above } \\
469 \mathrm{mb}\end{array}$ \\
\hline $\mathrm{NA}$ & -5.93 & $7.43(2.7)$ & -2.29 & 2.87 & 0.39 & 0.141 \\
$\mathrm{EU}$ & -3.59 & $7.48(2.7)$ & -1.88 & 3.92 & 0.52 & 0.043 \\
$\mathrm{FSU}$ & -2.16 & $8.78(3.2)$ & -0.70 & 2.84 & 0.32 & 0.041 \\
$\mathrm{AF}$ & -1.65 & $8.30(2.2)$ & -0.63 & 3.19 & 0.38 & 0.179 \\
$\mathrm{IN}$ & -1.06 & $9.27(3.4)$ & -0.68 & 5.90 & 0.64 & 0.394 \\
$\mathrm{EA}$ & -2.39 & $6.00(2.2)$ & -1.03 & 2.58 & 0.43 & 0.197 \\
$\mathrm{SA}$ & -1.08 & $13.20(4.8)$ & -0.66 & 8.02 & 0.61 & 0.397 \\
$\mathrm{SE}$ & -0.86 & $13.19(4.8)$ & -0.59 & 9.08 & 0.69 & 0.615 \\
$\mathrm{AU}$ & -0.35 & $9.22(3.4)$ & -0.24 & 6.20 & 0.67 & 0.177 \\
\hline
\end{tabular}

a The $\Delta \mathrm{B}_{\mathrm{NOy}} / \Delta \mathrm{E}_{\mathrm{NOx}}$ is expressed as a lifetime of $\mathrm{NO}_{\mathrm{y}}$ in parenthesis (days) associated with the regional change in $\mathrm{NO}_{\mathrm{x}}$ emissions, assuming the lifetime is not changed significantly by the small $\mathrm{NO}_{\mathrm{x}}$ emission change.

of greatest transpacific transport (Wild and Akimoto, 2001; Liu et al., 2003; Sudo and Akimoto, 2007). In Tables 6 and 7, a larger fraction of the $\mathrm{NO}_{\mathrm{y}}$ burden change occurs in the upper troposphere for EA than for NA and EU, but the fraction of the ozone production change in the upper troposphere is greater for NA than EA. More importantly, Tables 6 and 7 suggest that vertical pollutant transport will be relatively more important for tropical source regions (SE, IN, and SA), for which inter-continental air pollutant transport has received less attention in the literature.

Table 6 also shows that, for all source regions, a majority of the change in ozone production occurs over the source region itself, although most of the change in global ozone burden is outside of the source region. For most regions, the decrease in the net export of ozone is greater than the decrease in ozone production outside of the source region (last two columns of Table 6), suggesting that while the export of $\mathrm{NO}_{\mathrm{y}}$ contributes to long-range ozone transport, the direct export of ozone formed over the source region itself is more important. However, the change in production outside of the source region is greater than the change in export for three regions, EU, NA, and AU. For EU, and to a lesser extent $\mathrm{NA}$, the $\mathrm{NO}_{\mathrm{x}}$ reductions in winter cause ozone to increase over the source region, while $\mathrm{NO}_{\mathrm{y}}$ is exported and can form ozone elsewhere. The annual average decrease in export is less than the decrease in production outside of the source region, although this result may differ in the summer. For $\mathrm{AU}$, the source region is small and a lack of NMVOCs may contribute to low ozone production over the source region itself. Table 7 shows that for the reduction in AU, a majority of the global change in $\mathrm{NO}_{\mathrm{y}}$ burden occurs outside of the source region, and with greater sensitivity to $\mathrm{NO}_{\mathrm{x}}$ in the $\mathrm{SH}$, this causes the change in production of ozone outside of the source region to exceed the change in ozone export.
Figure 7 shows the change in the global tropospheric $\mathrm{NO}_{\mathrm{y}}$ burden associated with the decreases in regional $\mathrm{NO}_{\mathrm{x}}$ emissions. While the change in ozone burden occurs mainly outside of the source region, the fractional change in $\mathrm{NO}_{\mathrm{y}}$ burden outside of the source region varies between $32 \%$ and $69 \%$ among the different regions, with relatively more of the change in $\mathrm{NO}_{\mathrm{y}}$ burden occurring outside of the source regions in the tropics and SH (Table 7).

When NMVOC and $\mathrm{CO}$ emissions are reduced in addition to $\mathrm{NO}_{\mathrm{x}}$, the decreases in ozone burden and production are greater than when $\mathrm{NO}_{\mathrm{x}}$ is reduced alone, with a larger relative response for the reduction in EU (Table 8), in agreement with the changes for surface ozone (comparing Table 4 to Table 2). Relative to Table 6 , the NMVOC and CO reductions cause a greater decrease in ozone exported from the source regions. However, the change in ozone production outside of the source region, relative to Table 6 , is much larger than the change in export, and in fact, most of the global change in ozone production is accounted for by the change in ozone production outside of the source region. When reducing all precursors, we see that the decrease in ozone production outside of the source region is now greater than the decrease in export from the source region for all three regions. In agreement, Table 8 shows that the fraction of the change in ozone burden and production above the source region is smaller than in Table 8, while the fraction of ozone production in the upper troposphere is greater.

In Table 9, reducing NMVOC and $\mathrm{CO}$ emissions in addition to $\mathrm{NO}_{\mathrm{x}}$ causes a greater decrease in the global $\mathrm{NO}_{\mathrm{y}}$ burden, with much of this additional decrease (relative to Table 7) occurring outside of the source region. This can be explained in part by the importance of NVMOCs for producing PANs. By reducing NMVOCs, less of the $\mathrm{NO}_{\mathrm{x}}$ is converted to PANs and more to nitric acid $\left(\mathrm{HNO}_{3}\right)$. Since the lifetime of PANs is greater than $\mathrm{NO}_{\mathrm{x}}$ or $\mathrm{HNO}_{3}$, the mean lifetime 


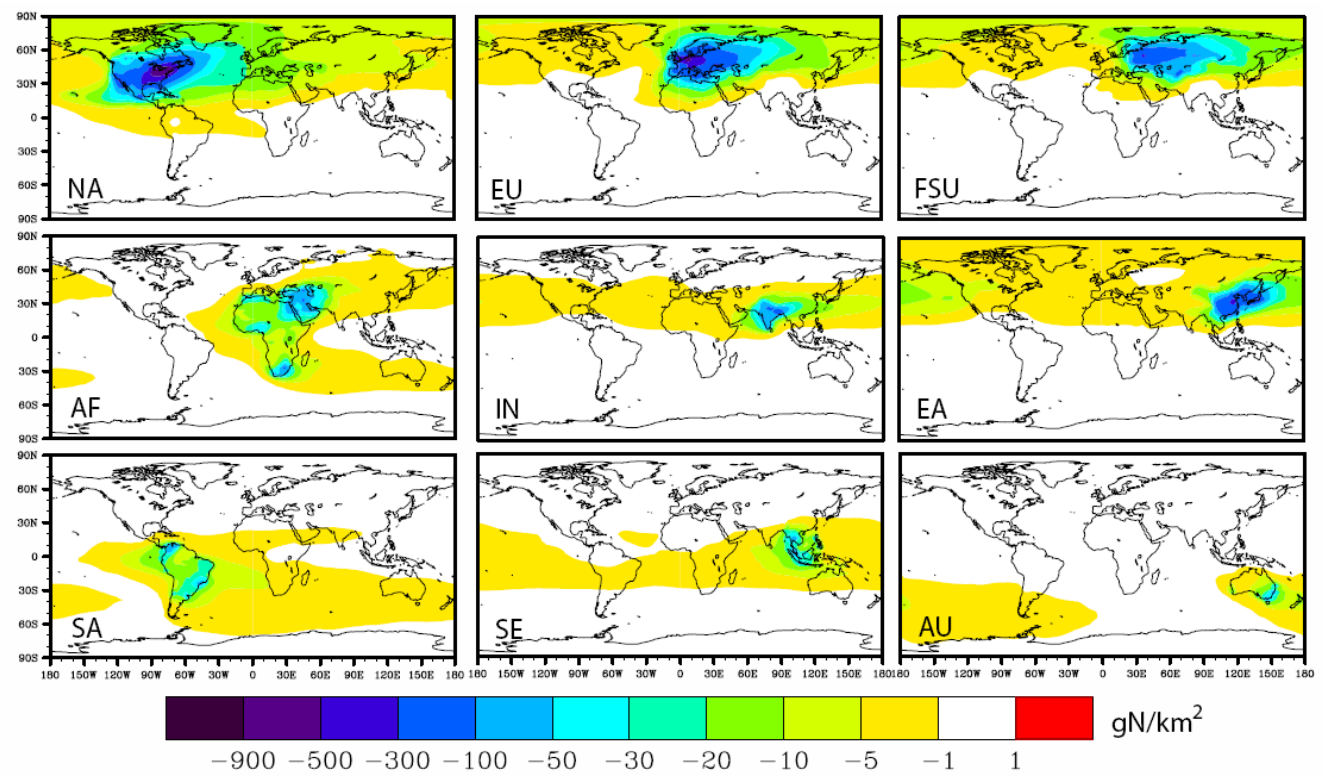

Fig. 7. Change in the annual average tropospheric burden of $\mathrm{NO}_{\mathrm{y}}$ due to $10 \%$ reductions of anthropogenic $\mathrm{NO}_{\mathrm{x}}$ emissions from each region.

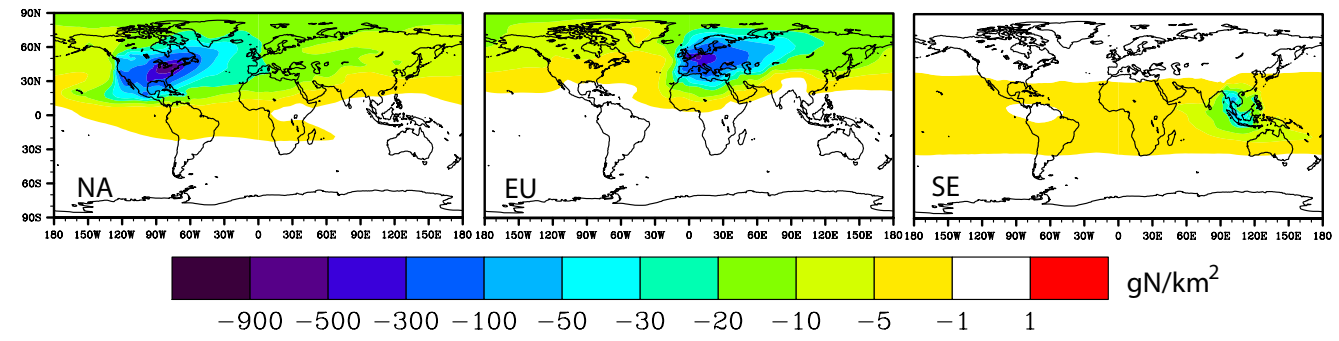

Fig. 8. As Fig. 7 but for the simulations where anthropogenic $\mathrm{NO}_{\mathrm{x}}, \mathrm{NMVOC}$, and $\mathrm{CO}$ emissions are reduced by $10 \%$.

of $\mathrm{NO}_{\mathrm{y}}$ decreases, as does its burden. Additionally, $\mathrm{CO}$ decreases can cause $\mathrm{OH}$ to increase, leading to faster conversion of $\mathrm{NO}_{\mathrm{x}}$ to $\mathrm{HNO}_{3}$, which also shortens the $\mathrm{NO}_{\mathrm{y}}$ lifetime. Accordingly, the fraction of the change in $\mathrm{NO}_{\mathrm{y}}$ burden outside of the source region is greater in Table 9 than in Table 7. Likewise, Fig. 8 shows a more widespread change in $\mathrm{NO}_{\mathrm{y}}$ burden than in Fig. 7.

These findings together suggest that the decreases in NMVOC and CO emissions are important for long-range ozone transport, and have perhaps been underemphasized in past analyses of long-range transport. Likewise, Fiore et al. (2009) find that the ratio of impacts from foreign sources relative to domestic sources is greater for changes in NMVOCs and $\mathrm{CO}$ emissions than for $\mathrm{NO}_{\mathrm{x}}$. We do not attempt to distinguish the relative importance of NMVOCs and CO for longrange transport, but Fiore et al. (2009) find that a $20 \%$ decrease in anthropogenic NMVOC emissions causes greater impacts on both intra- and inter-regional ozone than does a $20 \%$ decease in anthropogenic $\mathrm{CO}$.

\section{Conclusions}

Here we analyze the effects of $10 \%$ reductions in anthropogenic emissions of $\mathrm{NO}_{\mathrm{x}}$ from nine world regions on the long-range transport of ozone. The results identify the source-receptor pairs for which the long-range transport influence is greatest: EU on FSU (comparable to the influence within EU itself), EA on SE, and EU on AF, for threemonth population-weighted ozone metrics. Most other interregional influences are roughly a factor of 10 smaller than the ozone influence within the source region. By normalizing these results per unit of $\mathrm{NO}_{\mathrm{x}}$ reduced, we consider the relative efficacy of emission controls in different regions. For example, we find that $\mathrm{NO}_{\mathrm{x}}$ reductions in NA are $\sim 20 \%$ as effective at improving ozone air quality in $\mathrm{EU}$ as reductions in EU itself. For $\mathrm{NO}_{\mathrm{x}}$ reductions in NA to be costeffective at reducing ozone in EU (without considering the benefits of ozone reductions in NA) they would have to cost less than $20 \%$ per ton of the cost of $\mathrm{NO}_{\mathrm{x}}$ reductions in $\mathrm{EU}$. 
Table 8. As Table 6, for the simulations where $\mathrm{NO}_{\mathrm{x}}, \mathrm{NMVOCs}$, and $\mathrm{CO}$ are reduced simultaneously ("ratio to reducing only $\mathrm{NO}_{\mathrm{x}}$ " compares to results in Table 6).

\begin{tabular}{|c|c|c|c|c|c|c|c|c|c|c|c|c|c|}
\hline & $\begin{array}{l}\text { Anthrop. } \\
\quad \text { CO } \\
\text { emissions } \\
\left(\mathrm{Tg} \mathrm{yr}^{-1}\right)\end{array}$ & $\begin{array}{l}\text { Anthrop. } \\
\text { NVMOC } \\
\text { emissions } \\
\left(\mathrm{TgC} \mathrm{yr}^{-1}\right)\end{array}$ & $\begin{array}{c}\Delta \mathrm{B}_{\mathrm{O} 3} \\
\left(\mathrm{TgO}_{3}\right)\end{array}$ & $\begin{array}{l}\Delta \mathrm{B}_{\mathrm{O} 3} \\
\text { ratio to } \\
\text { reducing } \\
\text { only } \\
\mathrm{NO}_{\mathrm{x}}\end{array}$ & $\begin{array}{c}\Delta \mathrm{P}_{\mathrm{O} 3} \\
\left(\mathrm{TgO}_{3}\right. \\
\left.\mathrm{yr}^{-1}\right)\end{array}$ & $\begin{array}{l}\Delta \mathrm{P}_{\mathrm{O} 3} \\
\text { ratio to } \\
\text { reducing } \\
\text { only } \\
\mathrm{NO}_{\mathrm{X}}\end{array}$ & $\begin{array}{c}\text { Regional } \mathrm{O}_{3} \\
\text { lifetime } \\
\left(\Delta \mathrm{B}_{\mathrm{O} 3} /\right. \\
\left.\Delta \mathrm{P}_{\mathrm{O} 3}\right) \\
\text { (days) }\end{array}$ & $\begin{array}{c}\text { Global } \Delta \mathrm{O}_{3} \\
\text { lifetime } \\
(\mathrm{B} / \mathrm{P}) \\
\text { (days) }\end{array}$ & $\begin{array}{c}\text { Fraction } \\
\text { of global } \\
\Delta \mathrm{B}_{\mathrm{O} 3} \\
\text { above } \\
\text { source } \\
\text { region }\end{array}$ & $\begin{array}{c}\text { Fraction } \\
\text { of global } \\
\Delta \mathrm{P}_{\mathrm{O} 3} \\
\text { above } \\
\text { source } \\
\text { region }\end{array}$ & $\begin{array}{c}\text { Fraction } \\
\text { of global } \\
\Delta \mathrm{P}_{\mathrm{O} 3} \\
\text { above } \\
469 \mathrm{mb}\end{array}$ & $\begin{array}{l}\Delta \mathrm{X}_{\mathrm{O} 3} \\
\text { from } \\
\text { source } \\
\text { region } \\
\left(\mathrm{TgO}_{3}\right. \\
\left.\mathrm{yr}^{-1}\right)\end{array}$ & $\begin{array}{c}\Delta \mathrm{P}_{\mathrm{O} 3} \\
\text { outside } \\
\text { of source } \\
\text { region } \\
\left(\mathrm{TgO}_{3}\right. \\
\left.\mathrm{yr}^{-1}\right)\end{array}$ \\
\hline NA & 100.0 & 4.7 & -0.653 & 1.41 & -18.77 & 1.29 & 12.7 & 0.044 & 0.185 & 0.655 & 0.163 & -4.06 & -6.47 \\
\hline EU & 69.3 & 3.5 & -0.215 & 2.36 & -7.77 & 1.63 & 10.1 & 0.022 & 0.078 & 0.476 & 0.096 & -1.11 & -4.07 \\
\hline SE & 41.2 & 2.6 & -0.421 & 1.38 & -7.92 & 1.34 & 19.4 & 0.008 & 0.116 & 0.643 & 0.372 & -2.58 & -2.83 \\
\hline
\end{tabular}

Table 9. As Table 7, for the simulations where $\mathrm{NO}_{\mathrm{x}}, \mathrm{NMVOCs}$, and $\mathrm{CO}$ are reduced simultaneously ("ratio to reducing only $\mathrm{NO}_{\mathrm{x}}$ " compares to results in Table 7).

\begin{tabular}{ccccccc}
\hline $\begin{array}{c}\Delta \mathrm{B}_{\mathrm{NOy}} \\
(\mathrm{GgN})\end{array}$ & $\begin{array}{c}\Delta \mathrm{B}_{\mathrm{NOy}} \\
\text { ratio to } \\
\text { reducing } \\
\text { only } \mathrm{NO}_{\mathrm{x}}\end{array}$ & $\begin{array}{c}\Delta \mathrm{B}_{\mathrm{NOy}} \\
\text { outside of } \\
\text { source region } \\
(\mathrm{GgN})\end{array}$ & $\begin{array}{c}\Delta \mathrm{B}_{\mathrm{NOy}} \\
\text { outside of } \\
\text { source region } \\
\text { ratio to reducing } \\
\text { only } \mathrm{NO}_{\mathrm{x}}\end{array}$ & $\begin{array}{c}\text { Fraction of } \\
\Delta \mathrm{B}_{\mathrm{NOy}} \\
\text { outside of } \\
\text { source } \\
\text { region }\end{array}$ & $\begin{array}{c}\text { Fraction of } \\
\Delta \mathrm{B}_{\mathrm{NOy}} \\
\text { above } \\
469 \mathrm{mb}\end{array}$ \\
\hline $\mathrm{NA}$ & -6.51 & 1.10 & -2.79 & 1.22 & 0.43 & 0.159 \\
$\mathrm{EU}$ & -4.08 & 1.14 & -2.35 & 1.25 & 0.58 & 0.065 \\
$\mathrm{SE}$ & -1.13 & 1.31 & -0.84 & 1.42 & 0.74 & 0.608 \\
\hline
\end{tabular}

We similarly analyze the long-range transport influences on particular subregion receptors globally, showing that longrange influences can differ substantially among metropolitan areas in the same continental regions. The influences of $10 \%$ regional $\mathrm{NO}_{\mathrm{x}}$ reductions on long-range ozone transport are shown to vary strongly with season, where the seasons of greatest long-range transport often do not coincide with the seasons when ozone is highest in the receptor regions.

We find that the change in tropospheric ozone burden, and its long-range transport, per unit reduction in $\mathrm{NO}_{\mathrm{x}}$ emissions, is largest for source regions in the tropics and $\mathrm{SH}$. We attribute this high sensitivity to a relative lack of $\mathrm{NO}_{\mathrm{x}}$ in these regions, as well as greater photochemical activity, causing greater sensitivity of ozone production to changes in $\mathrm{NO}_{\mathrm{x}}$ in the lower troposphere. For tropical regions, the increased vertical transport of ozone and its precursors, due to greater convection, is a secondary cause of this enhanced sensitivity. For most source regions, the export of ozone from the source region is relatively more important for long-range transport than the reduced export of $\mathrm{NO}_{\mathrm{y}}$ and reduced production of ozone outside of the source region.

Reductions in emissions of NMVOCs and CO also influence ozone long-range transport; for some source-receptor pairs, reducing all three precursors more than doubles the long-range influence of $\mathrm{NO}_{\mathrm{x}}$ reductions alone. Relative to reducing $\mathrm{NO}_{\mathrm{x}}$ alone, also reducing NMVOCs and $\mathrm{CO}$ mainly influences the production of ozone outside of the source region. Reducing NMVOCs and $\mathrm{CO}$ causes the global $\mathrm{NO}_{\mathrm{y}}$ burden to decrease by reducing the production of PANs, thereby causing long-range influences on ozone. This re- search suggests that the importance of NMVOCs and CO for long-range transport may have been underemphasized in the past.

There are several important uncertainties and limitations in this work. Our findings are dependent on the definitions of different world regions used here, and should be evaluated through similar experiments in several different models. The emissions used in this study are uncertain and have changed since the early 1990s, particularly in less industrialized regions, and these uncertainties are expected to affect our estimates of the changes in ozone for $10 \%$ reductions, particularly for rapidly growing regions such as East Asia, with lesser importance for the effects per ton of emissions. The model is also biased high relative to measured surface ozone concentrations in some $\mathrm{NH}$ regions, particularly in summer. Our results are also limited to the $10 \%$ anthropogenic emission control experiments simulated here; Wu et al. (2009) find that inter-continental ozone transport in the $\mathrm{NH}$ scales nearly linearly with reductions of $\mathrm{NO}_{\mathrm{x}}$ in the summer and NMVOCs year-round, but strongly nonlinearly with $\mathrm{NO}_{\mathrm{x}}$ reductions outside of the summer. Finally, these results are based on one year of typical meteorological conditions, which do not necessarily reflect the multi-year average conditions, nor the conditions for maximum long-range transport. The inter-annual variability in transport conditions should be further studied for multiple source-receptor pairs, beyond the existing studies for particular regions (Duncan and Bey, 2004; Liu et al., 2003, 2005). In addition to improving emission estimates, future research should improve our understanding of the physical 
and chemical processes important for the long-range transport of ozone and its precursors, emphasizing the comparison of model results with satellite and in situ measurements, and combining regional and global models.

Acknowledgements. We thank J. Liu, D. Mauzerall, and H. Levy II for helpful conversations. This work was supported by the National Oceanic and Atmospheric Administration.

Edited by: B. N. Duncan

\section{References}

Akimoto, H.: Global air quality and pollution, Science, 302, 17161719, 2003.

Berntsen, T. K., Karlsdottir, S., and Jaffe, D. A.: Influence of Asian emissions on the composition of air reaching the North Western United States, Geophys. Res. Lett., 26, 2171-2174, 1999.

Berntsen, T. K., Fuglestvedt, J. S., Joshi, M. M., Shine, K. P., Stuber, N., Ponater, M., Sausen, R., Hauglustaine, D. A., and Li, L.: Response of climate to regional emissions of ozone precursors: sensitivities and warming potentials, Tellus B, 57, 283-304, 2005.

Derwent, R. G., Stevenson, D. S., Collins, W. J., and Johnson, C. E.: Intercontinental transport and the origins of the ozone observed at surface sites in Europe, Atmos. Environ., 38, 18911901, 2004

Derwent, R. G., Stevenson, D. S., Doherty, R. M., Collins, W. J., and Sanderson, M. G.: How is surface ozone in Europe linked to Asian and North American $\mathrm{NO}_{\mathrm{x}}$ emissions?, Atmos. Environ., 42, 7412-7422, 2008.

Duncan, B. N. and Chameides, W. L.: Effects of urban emission control strategies on the export of ozone and ozone precursors from the urban atmosphere to the troposphere, J. Geophys. Res., 103, 28159-28179, 1998.

Duncan, B. N. and Bey, I.: A modeling study of the export pathways of pollution from Europe: Seasonal and interannual variations (1987-1997), J. Geophys. Res., 109, D08301, doi:10.1029/2003JD004079, 2004.

Duncan, B. N., West, J. J., Yoshida, Y., Fiore, A. M., and Ziemke, J. R.: The influence of European pollution on ozone in the Near East and northern Africa, Atmos. Chem. Phys., 8, 2267-2283, 2008, http://www.atmos-chem-phys.net/8/2267/2008/.

Fiore, A., Jacob, D. J., Liu, H., Yantosca, R. M., Fairlie, T. D., and Li, Q.: Variability in surface ozone background over the United States: Implications for air quality policy, J. Geophys. Res., 108, 4787, doi:10.1029/2003JD003855, 2003.

Fiore, A. M., Jacob, D. J., Bey, I., Yantosca, R. M., Field, B. D., Fusco, A. C., and Wilkinson, J. G.: Background ozone over the United States in summer: Origin, trend, and contribution to pollution episodes, J. Geophys. Res., 107, 4275, doi:10.1029/2001JD000982, 2002.

Fiore, A. M., Dentener, F. J., Wild, O., Cuvelier, C., Schultz, M. G., Textor, C., Schulz, M., Atherton, C., Bergmann, D., Bey, I., Carmichael, G., Collins, W. J., Duncan, B. N., Faluvegi, G., Folberth, G., Gauss, M., Gong, S., Hauglustaine, D., Holloway, T., Isaksen, I. S. A., Jacob, D. J., Jonson, J. E., Kaminski, J.
W., Keating, T. J., Lupu, A., Marmer, E., Montanaro, V., Park, R. J., Pitari, G., Pringle, K. J., Pyle, J. A., Schroeder, S., Vivanco, M. G., Wind, P., Wojcik, G., Wu, S., and Zuber, A.: Multi-model Estimates of Intercontinental Source-Receptor Relationships for Ozone Pollution, J. Geophys. Res., 114, D04301, doi:10.1029/2008JD010816, 2009.

Forster, P., Ramaswamy, V., Artaxo, P., Berntsen, T., Betts, R., Fahey, D. W., Haywood, J., Lean, J., Lowe, D. C., Myhre, G., Nganga, J., Prinn, R., Raga, G., Schulz, M., and Van Dorland, R.: Changes in Atmospheric Constituents and in Radiative Forcing, in: Climate Change 2007: The Physcial Science Basis, edited by: Solomon, S., Qin, D., Manning, M., Chen, Z., Marquis, M., Averyt, K. B., Tignor, M., and Miller, H. L., Cambridge University Press, New York, USA, 129-234, 2007.

Fuglestvedt, J. S., Berntsen, T. K., Isaksen, I. S. A., Mao, H. T., Liang, X. Z., and Wang, W. C.: Climatic forcing of nitrogen oxides through changes in tropospheric ozone and methane; global 3-D model studies, Atmos. Environ., 33, 961-977, 1999.

Heald, C. L., Jacob, D. J., Fiore, A. M., Emmons, L. K., Gille, J. C., Deeter, M. N., Warner, J., Edwards, D. P., Crawford, J. H., Hamlin, A. J., Sachse, G. W., Browell, E. V., Avery, M. A., Vay, S. A., Westberg, D. J., Blake, D. R., Singh, H. B., Sandholm, S. T., Talbot, R. W., and Fuelberg, H. E.: Asian outflow and transPacific transport of carbon monoxide and ozone pollution: An integrated satellite, aircraft, and model perspective, J. Geophys. Res., 108, 4804, doi:10.1029/2003JD003507, 2003.

Hess, P. G. and Lamarque, J. F.: Ozone source attribution and its modulation by the Arctic oscillation during the spring months, J. Geophys. Res., 112, D11303, doi:10.1029/2006JD007557, 2007.

Holloway, T., Fiore, A., and Hastings, M. G.: Intercontinental Transport of air pollution: Will emerging science lead to a new hemispheric treaty?, Environ. Sci. Technol., 37, 4535-4542, 2003.

Holloway, T., Sakurai, T., Han, Z., Ehlers, S., Spak, S. N., Horowitz, L. W., Carmichael, G. R., Streets, D. G., Hozumi, Y., Ueda, H., Park, S. U., Fung, C., Kajino, M., Thongboonchoo, N., Engardt, M., Bennet, C., Hayami, H., Sartelet, K., Wang, Z., Matsuda, K., and Amann, M.: MICS-Asia II: Impact of global emissions on regional air quality in Asia, Atmos. Environ., 42, 3543-3561, 2008.

Horowitz, L. W. and Jacob, D. J.: Global impact of fossil fuel combustion on atmospheric $\mathrm{NO}_{\mathrm{X}}$, J. Geophys. Res., 104, 23823 23840, 1999.

Horowitz, L. W., Walters, S., Mauzerall, D. L., Emmons, L. K., Rasch, P. J., Granier, C., Tie, X. X., Lamarque, J. F., Schultz, M. G., Tyndall, G. S., Orlando, J. J., and Brasseur, G. P.: A global simulation of tropospheric ozone and related tracers: Description and evaluation of MOZART, version 2, J. Geophys. Res., 108, 4784, doi:10.1029/2002JD002853, 2003.

Hudman, R. C., Jacob, D. J., Cooper, O. R., Evans, M. J., Heald, C. L., Park, R. J., Fehsenfeld, F., Flocke, F., Holloway, J., Hubler, G., Kita, K., Koike, M., Kondo, Y., Neuman, A., Nowak, J., Oltmans, S., Parrish, D., Roberts, J. M., and Ryerson, T.: Ozone production in transpacific Asian pollution plumes and implications for ozone air quality in California, J. Geophys. Res., 109, D23S10, doi:10.1029/2004JD004974, 2004.

Jacob, D. J., Logan, J. A., and Murti, P. P.: Effect of rising Asian emissions on surface ozone in the United States, Geophys. Res. Lett., 26, 2175-2178, 1999. 
Kunhikrishnan, T. and Lawrence, M. G.: Sensitivity of $\mathrm{NO}_{\mathrm{x}}$ over the Indian Ocean to emissions from the surrounding continents and nonlinearities in atmospheric chemistry responses, Geophys. Res. Lett., 31, L15109, doi:10.1029/2004GL020210, 2004.

Kunhikrishnan, T., Lawrence, M. G., von Kuhlmann, R., Richter, A., Ladstatter-Weissenmayer, A., and Burrows, J. P.: Analysis of tropospheric $\mathrm{NO}_{\mathrm{x}}$ over Asia using the model of atmospheric transport and chemistry (MATCH-MPIC) and GOME-satellite observations, Atmos. Environ., 38, 581-596, 2004.

Kunhikrishnan, T., Lawrence, M. G., von Kuhlmann, R., Wenig, M. O., Asman, W. A. H., Richter, A., and Burrows, J. P.: Regional $\mathrm{NO}_{\mathrm{x}}$ emission strength for the Indian subcontinent and the impact of emissions from India and neighboring countries on regional O-3 chemistry, J. Geophys. Res., 111, D15301, doi:10.1029/2005JD006036, 2006.

Lawrence, M. G., von Kuhlmann, R., Salzmann, M., and Rasch, P. J.: The balance of effects of deep convective mixing on tropospheric ozone, Geophys. Res. Lett., 30, 1940, doi:10.1029/2003GL017644, 2003.

Lelieveld, J. and Dentener, F. J.: What controls tropospheric ozone?, J. Geophys. Res., 105, 3531-3551, 2000.

Li, Q. B., Jacob, D. J., Bey, I., Palmer, P. I., Duncan, B. N., Field, B. D., Martin, R. V., Fiore, A. M., Yantosca, R. M., Parrish, D. D., Simmonds, P. G., and Oltmans, S. J.: Transatlantic transport of pollution and its effects on surface ozone in Europe and North America, J. Geophys. Res., 107, D001422, doi:10.1029/2001JD001422, 2002.

Liang, J. Y., Horowitz, L. W., Jacob, D. J., Wang, Y. H., Fiore, A. M., Logan, J. A., Gardner, G. M., and Munger, J. W.: Seasonal budgets of reactive nitrogen species and ozone over the United States, and export fluxes to the global atmosphere, J. Geophys. Res., 103, 13435-13450, 1998.

Lin, J. T., Wuebbles, D. J., and Liang, X. Z.: Effects of intercontinental transport on surface ozone over the United States: Present and future assessment with a global model, Geophys. Res. Lett., 35, L02805, doi:10.1029/2007GL031415, 2008.

Liu, H. Y., Jacob, D. J., Bey, I., Yantosca, R. M., Duncan, B. N., and Sachse, G. W.: Transport pathways for Asian pollution outflow over the Pacific: Interannual and seasonal variations, J. Geophys. Res., 108, 8786, doi:10.1029/2002JD003102, 2003.

Liu, J. F., Mauzerall, D. L., and Horowitz, L. W.: Analysis of seasonal and interannual variability in transpacific transport, J. Geophys. Res., 110, D04302, doi:10.1029/2004JD005207, 2005.

Mauzerall, D. L., Narita, D., Akimoto, H., Horowitz, L., Walters, S., Hauglustaine, D. A., and Brasseur, G.: Seasonal characteristics of tropospheric ozone production and mixing ratios over East Asia: A global three-dimensional chemical transport model analysis, J. Geophys. Res., 105, 17895-17910, 2000.

Moxim, W. J., Levy, H., and Kasibhatla, P. S.: Simulated global tropospheric PAN: Its transport and impact on $\mathrm{NO}_{\mathrm{X}}$, J. Geophys. Res., 101, 12621-12638, 1996.

Naik, V., Mauzerall, D., Horowitz, L., Schwarzkopf, M. D., Ramaswamy, V., and Oppenheimer, M.: Net radiative forcing due to changes in regional emissions of tropospheric ozone precursors, J. Geophys. Res., 110, D24306, doi:10.1029/2005JD005908, 2005.

National Research Council: Rethinking the ozone problem in urban and regional air pollution, National Academy Press, Washington, DC, 534 pp., 1991.
Newell, R. E. and Evans, M. J.: Seasonal changes in pollutant transport to the North Pacific: the relative importance of Asian and European sources, Geophys. Res. Lett., 27, 2509-2512, 2000.

Oak Ridge National Laboratory: Land Scan 2003, http://www.ornl. gov/sci/landscan., 2005.

Olivier, J. G. J., Bouwman, A. F., van der Maas, C. W. M., Berdowski, J. J. M., Veldt, C., Bloos, J. P. J., Visschedijk, A. J. H., Zandveld, P. Y. J., and Haverlag, J. L.: Description of EDGAR version 2.0: A set of global emission inventories of greenhouse gases and ozone-depleting substances for all anthropogenic and most natural sources on a per country basis and on a $1 \times 1$ degree grid, RIVM Rep. 771060 002/TNO-MEP Rep. R96/119, Natl. Inst. of Public Health and Environ., Biltoven, Netherlands, 1996.

Phadnis, M. J. and Carmichael, G. R.: Transport and distribution of primary and secondary nonmethane volatile organic compounds in east Asia under continental outflow conditions, J. Geophys. Res., 105, 22311-22336, 2000.

Richter, A., Burrows, J. P., Nuss, H., Granier, C., and Niemeier, U.: Increase in tropospheric nitrogen dioxide over China observed from space, Nature, 437, 129-132, 2005.

Schultz, M., Rast, S., van het Bolscher, M., Pulles, T., Brand, R., Pereira, J., Mota, B., Spessa, A., Dalsoren, S., Nojie, T. v., and Szopa, S.: Emission data sets and methodologies for estimating emissions, RETRO project, Work Package 1, Deliverable D1-6, http://retro.enes.org, 2007.

Stevenson, D. S., Dentener, F. J., Schultz, M. G., Ellingsen, K., van Noije, T. P. C., Wild, O., Zeng, G., Amann, M., Atherton, C. S., Bell, N., Bergmann, D. J., Bey, I., Butler, T., Cofala, J., Collins, W. J., Derwent, R. G., Doherty, R. M., Drevet, J., Eskes, H. J., Fiore, A. M., Gauss, M., Hauglustaine, D. A., Horowitz, L. W., Isaksen, I. S. A., Krol, M. C., Lamarque, J. F., Lawrence, M. G., Montanaro, V., Muller, J. F., Pitari, G., Prather, M. J., Pyle, J. A., Rast, S., Rodriguez, J. M., Sanderson, M. G., Savage, N. H., Shindell, D. T., Strahan, S. E., Sudo, K., and Szopa, S.: Multimodel ensemble simulations of present-day and near-future tropospheric ozone, J. Geophys. Res., 111, D08301, doi:10.1029/2005JD006338, 2006.

Stohl, A.: Intercontinental Transport of Air Pollution, The Handbook of Environmental Chemistry, 325 pp., Springer-Verlag, Berlin, 2004.

Stohl, A. and Trickl, T.: A textbook example of long-range transport: Simultaneous observation of ozone maxima of stratospheric and North American origin in the free troposphere over Europe, J. Geophys. Res., 104, 30445-30462, 1999.

Stohl, A., Forster, C., Eckhardt, S., Spichtinger, N., Huntrieser, H., Heland, J., Schlager, H., Wilhelm, S., Arnold, F., and Cooper, O.: A backward modeling study of intercontinental pollution transport using aircraft measurements, J. Geophys. Res., 108, 4370, doi:10.1029/2002JD002862, 2003.

Sudo, K. and Akimoto, H.: Global source attribution of tropospheric ozone: Long-range transport from various source regions, J. Geophys. Res., 112, D12302, doi:10.1029/2006JD007992, 2007.

Task Force on Hemispheric Transport of Air Pollution: Hemispheric Transport of Air Pollution 2007, United Nations Economic Commission for Europe, Geneva, 147 pp., 2007.

Trickl, T., Cooper, O. R., Eisele, H., James, P., Mucke, R., and Stohl, A.: Intercontinental transport and its influence on the 
ozone concentrations over central Europe: Three case studies, J. Geophys. Res., 108, 8530, doi:10.1029/2002JD002735, 2003.

Vingarzan, R.: A review of surface ozone background levels and trends, Atmos. Environ., 38, 3431-3442, 2004.

Wang, Y. H. and Jacob, D. J.: Anthropogenic forcing on tropospheric ozone and $\mathrm{OH}$ since preindustrial times, J. Geophys. Res., 103, 31123-31135, 1998.

Wang, Y. H., Jacob, D. J., and Logan, J. A.: Global simulation of tropospheric $\mathrm{O}_{3}-\mathrm{NO}_{\mathrm{x}}$-hydrocarbon chemistry 3 . Origin of tropospheric ozone and effects of nonmethane hydrocarbons, J. Geophys. Res., 103, 10757-10767, 1998.

West, J. J., Fiore, A. M., Naik, V., Horowitz, L. W., Schwarzkopf, M. D., and Mauzerall, D. L.: Ozone air quality and radiative forcing consequences of changes in ozone precursor emissions, Geophys. Res. Lett., 34, L06806, doi:10.1029/2006GL029173, 2007.

West, J. J., Naik, V., Horowitz, L. W., and Fiore, A. M.: Effect of regional precursor emission controls on long-range ozone transport - Part 2: Steady-state changes in ozone air quality and impacts on human mortality, Atmos. Chem. Phys., 9, 6095-6107, 2009, http://www.atmos-chem-phys.net/9/6095/2009/.

Wild, O. and Akimoto, H.: Intercontinental transport of ozone and its precursors in a three-dimensional global CTM, J. Geophys. Res., 106, 27729-27744, 2001.
Wild, O., Prather, M. J., and Akimoto, H.: Indirect long-term global radiative cooling from $\mathrm{NO}_{\mathrm{x}}$ emissions, Geophys. Res. Lett., 28, 1719-1722, 2001.

Wild, O., Pochanart, P., and Akimoto, H.: Trans-Eurasian transport of ozone and its precursors, J. Geophys. Res., 109, D11302, doi:10.1029/2003JD004501, 2004.

Wu, S., Duncan, B. N., Jacob, D. J., Fiore, A. M., and Wild, O.: Chemical nonlinearities in relating intercontinental ozone pollution to anthropogenic emissions, Geophys. Res. Lett., 36, L05806, doi:10.1029/2008GL036607, 2009.

Yienger, J. J., Galanter, M., Holloway, T. A., Phadnis, M. J., Guttikunda, S. K., Carmichael, G. R., Moxim, W. J., and Levy, H.: The episodic nature of air pollution transport from Asia to North America, J. Geophys. Res., 105, 26931-26945, 2000.

Zhang, L., Jacob, D. J., Boersma, K. F., Jaffe, D. A., Olson, J. R., Bowman, K. W., Worden, J. R., Thompson, A. M., Avery, M. A., Cohen, R. C., Dibb, J. E., Flock, F. M., Fuelberg, H. E., Huey, L. G., McMillan, W. W., Singh, H. B., and Weinheimer, A. J.: Transpacific transport of ozone pollution and the effect of recent Asian emission increases on air quality in North America: an integrated analysis using satellite, aircraft, ozonesonde, and surface observations, Atmos. Chem. Phys., 8, 6117-6136, 2008, http://www.atmos-chem-phys.net/8/6117/2008/. 